\title{
Partial purification and characterisation of two actinomycete tyrosinases and their application in cross-linking reactions
}

Marilize Le Roes-Hill ${ }^{1}$, Zaida Palmer ${ }^{1}$, Jeffrey Rohland ${ }^{1}$, Bronwyn Michelle Kirby ${ }^{2}$ and Stephanie Gail Burton ${ }^{3}$

${ }^{1}$ Biocatalysis and Technical Biology Research Group, Institute of Biomedical and Microbial Biotechnology, Cape

Peninsula University of Technology, PO Box 1906, Bellville, 7535, South Africa

${ }^{2}$ Institute for Microbial Biotechnology and Metagenomics, University of the Western Cape, Private Bag X17, Bellville, 7535, South Africa

${ }^{3}$ Vice-Principal: Research and Postgraduate Education and Department of Biochemistry, University of Pretoria, Private Bag X20, Hatfield, Pretoria, 0028, South Africa

Corresponding author: Marilize Le Roes-Hill

E-mail: leroesm@cput.ac.za

Telephone: +27-21-953-8499

Note: Nucleotide sequence data reported are available in the GenBank database under the accession numbers KR030065, KR030066, KR030067 and KR030068.

\section{Highlights:}

- Partial purification of two extracellular tyrosinases from Streptomyces spp.

- Organic solvent resistance exhibited by tyrosinases

- Atypical characteristics, e.g. resistance to arbutin and SDS

- Catalysed cross-linking reactions of proteins, e.g. gelatine and casein

\begin{abstract}
Actinomycetes are a ubiquitous group of bacteria, and are hypothesised to produce tyrosinases for protection against the potential toxic effect of phenolic compounds and for the production of melanin. In this study, tyrosinase production by Streptomyces pharetrae CZA14 ${ }^{\top}$ (CZA14Tyr) and Streptomyces polyantibioticus $\mathrm{SPR}^{\top}$ (SPRTyr) was optimised. The enzymes were partially
\end{abstract}


purified and biochemically characterised to determine their suitability for industrial applications. SPRTyr was stable up to $40^{\circ} \mathrm{C}$ and at $\mathrm{pH} 4.5-10.0$, while CZA14Tyr was stable up to $40^{\circ} \mathrm{C}$ and at $\mathrm{pH}$ 6.5-10.0. The enzymes showed variable stability in the presence of water-miscible organic solvents and were able to oxidize L-DOPA in the presence of these solvents. A limited inhibitory effect was observed with arbutin, EDTA, sodium chloride and sodium dodecyl sulphate, while both enzymes were strongly inhibited by the reducing agents used in this study. Inhibition of enzyme activity was observed in the presence of $1 \mathrm{mM} \mathrm{Cu}^{2+}$ and $5 \mathrm{mM} \mathrm{Co}^{2+}$ for SPRTyr, and 5 $\mathrm{mM} \mathrm{Fe}^{2+}$ and $5 \mathrm{mM} \mathrm{Zn}^{2+}$ for CZA14Tyr. When applied in various cross-linking reactions both tyrosinases were able to cross-link casein and gelatine in the absence of a phenolic compound, showing potential for application in the food industry and for the production of biomaterials.

Keywords:

biochemical characterisation, cross-linking, industrial application, Streptomyces, tyrosinase

\section{Introduction}

Tyrosinases (EC 1.14.18.1) are Type III copper proteins that utilise molecular oxygen to catalyse two types of reactions: monophenolase and diphenolase (catechol oxidase) type reactions $[1,2]$. In the monophenolase reaction, the o-hydroxylation of a monophenol occurs to produce an odiphenol. The o-diphenol then serves as a substrate for the subsequent catechol oxidase reaction, resulting in the formation of $o$-quinones. In addition, tyrosinases have also been shown to catalyse the $o$-hydroxylation of aromatic amines and the oxidation of $o$-aminophenols to $o$ quinoneimines [3]. Tyrosinases, along with laccases (EC 1.10.3.2) and catechol oxidases (EC 1.10.3.1), are collectively known as phenol oxidases. However, it is only tyrosinases that are able to catalyse monophenolase type reactions, which is often used as a distinguishing feature in the biochemical description of phenol oxidases [1]. The Type III copper centre of tyrosinases consists of two copper atoms (CUA and CuB) that are co-ordinated by six highly conserved histidine residues (three residues per copper co-ordination) located in the active site [4]. The signature 
sequence around the CUA and CuB co-ordination sites are characterised by the sequences $\mathrm{H}$ $X(n)-H-X(8)-H$ and $H-X(3)-H-X(n)-H$, respectively $[1,5]$.

Tyrosinases are quite widespread in nature where they play various roles related to the health or pathogenicity of the producing organism [1]. In 1972, the first streptomycete tyrosinases were described: Streptomyces glaucescens [6] and Streptomyces nigrifaciens [7], but it is not clear whether the latter represents a true tyrosinase [2]. Very few streptomycete tyrosinases (less than twenty) have been isolated and described to date, which is quite surprising considering the fact that the genus currently consists of more than 600 validly published species (List of prokaryotic names with standing in nomenclature, 2015; http://www.bacterio.net/index.html). It has been proposed that there are three different types of tyrosinases in streptomycetes [8]: Type I or MeID (membrane bound, universal in streptomycetes, potential protective role against phenolics); Type II or MelC (secreted, sporadic occurrence in streptomycetes); and Type III (o-aminophenol oxidase, intracellular, rare, involved in secondary metabolite production). All three types of tyrosinases are encoded by bi-cistronic operons: one gene encodes for a chaperone or caddy protein and the downstream gene encodes for an inactive, apotyrosinase. For the streptomycete MelC extracellular tyrosinase, MelC1 is a copper chaperone involved in the binding of copper ions and the incorporation of copper into the apotyrosinase (MelC2). MelC1 is also responsible for the activation and secretion of the otherwise inactive apotyrosinase: MelC1 contains the twin arginine signal peptide sequence that allows for the export of the enzyme in its active form through the twin arginine translocation (TAT) secretion pathway [8]. In 2006, the crystal structure of the tyrosinase produced by Streptomyces castaneoglobisporus was elucidated, thereby providing a clearer understanding of the interaction of MelC1 with MelC2 during the formation of an active tyrosinase [9].

The ability of tyrosinases to oxidize mono- and diphenols has allowed for their applications in various biotechnological processes. The tyrosinase from Agaricus bisporus (common button mushroom) is most commonly utilized in research, largely because of its commercial availability 
[10]. However, the limitations of this tyrosinase (e.g. low solvent and heat stability) have encouraged researchers to look towards alternative sources of tyrosinases, including bacteria due to ease of genetic manipulation and over-expression in expression hosts such as Escherichia coli [10]. The biotechnological relevance of bacterial tyrosinases spans their application in bioremediation (detoxification of phenol-contaminated wastewater and soil), the production of synthetic melanins, their application in biocatalysis reactions (production of L-3,4dihydroxyphenylalanine or L-DOPA, and application in cross-linking reactions) and biosensor technology (detection of phenols and oxygen) $[10,11]$. In this study, tyrosinases from two novel streptomycetes, Streptomyces polyantibioticus $\mathrm{SPR}^{\top}$ and Streptomyces pharetrae $\mathrm{CZA} 14^{\top}$, were isolated and biochemically characterised (solvent stability, $\mathrm{pH}$ stability, thermostability, effect of inhibitors) to determine their suitability for application in industrial processes. The genome sequences of the two strains were analysed for the presence of bi-cistronic tyrosinase operons and the sequences subjected to bioinformatics analyses. Finally, both tyrosinases were applied in selected cross-linking reactions to determine their potential application in industries requiring covalent protein-protein cross-linking.

\section{Experimental}

\subsection{Materials/Chemicals Used in this Study}

All chemicals used in this study were obtained from Merck-Millipore (South Africa) and SigmaAldrich (South Africa), unless stated otherwise.

\subsection{Tyrosinase-Producing Strains}

S. polyantibioticus SPR ${ }^{\top}\left(=\mathrm{DSM} 44925^{\top}=\mathrm{NRRL} B-24448^{\top}\right.$ ) was isolated from soil collected from the banks of the Umgeni River, KwaZulu Natal, South Africa [12] and S. pharetrae CZA14 ${ }^{\top}$ $\left(=\mathrm{DSM} 41856^{\top}=\mathrm{JCM} 13860^{\top}=\mathrm{NRRL} \mathrm{B}-24333^{\top}\right)$ was isolated from soil collected from the base of a giant quiver tree, Karoo Desert National Botanical Gardens, Worcester, South Africa [13]. The strains were maintained on International Streptomyces Project (ISP) medium number 2 (ISP2 or 
Yeast extract-Malt Extract, YEME; g/L: 10.0 malt extract, 4.0 yeast extract, 4.0 glucose, 20.0 bacteriological agar, $\mathrm{pH} 7.3$ ) [14] and as stock cultures in $20 \%(\mathrm{v} / \mathrm{v})$ glycerol at $-20^{\circ} \mathrm{C}$.

\subsection{Screening for Tyrosinase Activity: Solid Media}

S. polyantibioticus SPR ${ }^{\top}$ and S. pharetrae $\mathrm{CZA} 14^{\top}$ were streaked onto various solid media for the detection of melanin production (which served as an indicator of tyrosinase production). The following media were used: YEME (ISP2); ISP medium number 6 (ISP6; g/L: 15.0 peptone, 5.0 proteose peptone, 0.5 ferric ammonium citrate, $1.0 \mathrm{~K}_{2} \mathrm{HPO}_{4}, 0.08 \mathrm{Na}_{2} \mathrm{~S}_{2} \mathrm{O}_{3}, 1.0$ yeast extract, 15.0 bacteriological agar, pH 7.0) [14]; ISP medium number 7 (ISP7; g/L: 15.0 glycerol, 0.5 Ltyrosine, 1.0 L-asparagine monohydrate, $0.5 \mathrm{~K}_{2} \mathrm{HPO}_{4}, 0.5 \mathrm{MgSO}_{4} .7 \mathrm{H}_{2} \mathrm{O}, 0.5 \mathrm{NaCl}, 0.01$ $\mathrm{FeSO}_{4} .7 \mathrm{H}_{2} \mathrm{O}, 1.0 \mathrm{ml}$ trace salts solution, 20.0 bacteriological agar, $\mathrm{pH}$ 7.2; Trace salts solution, g/100 ml: $0.1 \mathrm{FeSO}_{4} .7 \mathrm{H}_{2} \mathrm{O}, 0.1 \mathrm{MnCl}_{2} \cdot 4 \mathrm{H}_{2} \mathrm{O}, 0.1 \mathrm{ZnSO}_{4} .7 \mathrm{H}_{2} \mathrm{O}$, filter sterilize) [14]; DSMZ medium 553 (GPHF-medium, g/L: 10.0 glucose, 5.0 peptone, 5.0 yeast extract, 5.0 beef extract, 0.74 $\mathrm{CaCl}_{2} .2 \mathrm{H}_{2} \mathrm{O}, 15.0$ bacteriological agar, $\mathrm{pH} 7.2$ ); modified phenoxazinone production medium (MPPM; g/L: 10.0 glycerol, 10.0 glucose, 10.0 soya flour, 5.0 casamino acids, 5.0 yeast extract, 4.0 $\mathrm{CaCO}_{3}, 1 \mathrm{ml}$ trace salts solution, 15.0 bacteriological agar, $\mathrm{pH}$ 7.0; Trace salts solution, $\mathrm{g} / 100$ ml: 1.0 FeSO4; $0.9 \mathrm{ZnSO} 4,0.2 \mathrm{MnSO}_{4}$ ) [15]; and Czapek solution agar (CZ; g/L: 30.0 sucrose, 2.0 NaNO $3,1.0 \mathrm{~K}_{2} \mathrm{HPO}_{4}, 0.5 \mathrm{KCl}, 0.5 \mathrm{MgSO}_{4} .7 \mathrm{H}_{2} \mathrm{O}, 0.01 \mathrm{FeSO}_{4} .7 \mathrm{H}_{2} \mathrm{O}, 15.0$ bacteriological agar, $\mathrm{pH}$ to $7.3 \pm 0.2$ ) [16]. Streptomyces antibioticus NRRL B- $2770^{\top}$, a known tyrosinase producer, was included in all experiments as a positive control. Plates were incubated at $30^{\circ} \mathrm{C}$ for 7 days and monitored for the production of a dark brown to black pigment.

\subsection{Enzyme Production}

For the production of the tyrosinases, $10 \mathrm{ml}$ pre-cultures of the two tyrosinase-producing strains were prepared in MPPM: $100 \mu \mathrm{l}$ of the stock cultures was used to inoculate every $10 \mathrm{ml}$ volume pre-culture media. S. polyantibioticus $\mathrm{SPR}^{\top}$ was inoculated into MPPM, pH 5.5, while $S$. pharetrae CZA $14^{\top}$ was inoculated into MPPM, $\mathrm{pH}$ 6.5. The S. polyantibioticus $\mathrm{SPR}^{\top}$ and $S$. pharetrae $\mathrm{CZA} 14^{\top}$ pre-cultures were incubated for $48 \mathrm{~h}$ at $22^{\circ} \mathrm{C}$ and $30^{\circ} \mathrm{C}$, respectively, shaking 
at $160 \mathrm{rpm}$. For both strains, a $5 \%$ pre-culture inoculum $(20 \mathrm{ml})$ was used to inoculate a $400 \mathrm{ml}$ volume of MPPM (in a $2 \mathrm{~L}$ shake flask), which was supplemented with $4 \mathrm{ml} 100 \mathrm{mM}$ filter sterilised $\mathrm{CuSO}_{4} \cdot 5 \mathrm{H}_{2} \mathrm{O}$ (final concentration of $1 \mathrm{mM}$ ). The $400 \mathrm{ml}$ volume cultures were incubated as before, but only for $24 \mathrm{~h}$. The cultures were centrifuged at $10000 \mathrm{~g}$ for $5 \mathrm{~min}$ at $4^{\circ} \mathrm{C}$ and the culture supernatants used for the purification of the extracellular tyrosinases.

\subsubsection{Partial Purification of the Tyrosinases: Ammonium Sulphate Precipitation, Dialysis and Anion Exchange}

The culture supernatants from both strains were subjected to ammonium sulphate precipitation. The culture supernatant was initially brought to a $40 \%$ saturation level, stirred at $22^{\circ} \mathrm{C}$ for $1 \mathrm{~h}$ and centrifuged at $10000 \mathrm{~g}$ for $10 \mathrm{~min}$ at $4^{\circ} \mathrm{C}$. The resultant supernatant was brought to a $56 \%$ saturation level, stirred at $22^{\circ} \mathrm{C}$ for $1 \mathrm{~h}$ and centrifuged at $10000 \mathrm{~g}$ for $10 \mathrm{~min}$ at $4^{\circ} \mathrm{C}$. The pellets were resuspended in $50 \mathrm{mM}$ potassium phosphate buffer $\left(\mathrm{pH} \mathrm{6.5)}\right.$ and dialysed at $4^{\circ} \mathrm{C}$ for $24 \mathrm{~h}$ against ice-cold $50 \mathrm{mM}$ potassium phosphate buffer, $\mathrm{pH} 6.5$ (buffer replaced after the first $3 \mathrm{~h}$ and after $20 \mathrm{~h}$ ). After $24 \mathrm{~h}$, the dialysis buffer was replaced with a $20 \%$ (w/v) polyethylene glycol 8000 solution (prepared in $50 \mathrm{mM}$ potassium phosphate buffer, $\mathrm{pH}$ 6.5) to concentrate the enzyme solution (incubated at $4^{\circ} \mathrm{C}$ for $24 \mathrm{~h}$ ). The concentrate was redissolved in $50 \mathrm{mM}$ potassium phosphate buffer, pH 6.5, and applied to a DEAE Sephadex ${ }^{\mathrm{TM}}$ A-50 (GE Healthcare) column. The enzymes were eluted with $50 \mathrm{mM}$ potassium phosphate buffer, $\mathrm{pH}$ 6.5. The enzymes were designated SPRTyr for S. polyantibioticus SPR ${ }^{\top}$ tyrosinase and CZA14Tyr for S. pharetrae CZA $14^{\top}$ tyrosinase.

\subsubsection{Enzyme Activity}

Tyrosinase activity was determined using L-DOPA as a substrate: $10 \mathrm{mM}$ L-DOPA was prepared in $50 \mathrm{mM}$ potassium phosphate buffer $(\mathrm{pH} 6.5)$ [6] and its oxidation was monitored at $475 \mathrm{~nm}(\varepsilon=$ $3600 \mathrm{M}^{-1} \mathrm{~cm}^{-1}$ ) using an anthos Zenyth1100 microtiter plate reader. One unit of enzyme activity was defined as the amount of enzyme required to oxidize $1 \mu \mathrm{mol}$ of substrate per minute at $22 \pm$ 
$2^{\circ} \mathrm{C}$ (ambient temperature). Tyrosinase from S. antibioticus NRRL B- $2770^{\top}$ was used as a positive control.

\subsubsection{Protein Concentration Determination}

The protein concentrations of the enzymes were determined using the Bradford's assay [17]. A standard curve was produced using a range of bovine serum albumin (BSA) concentrations. $20 \mu \mathrm{l}$ of sample was added to $40 \mu \mathrm{l}$ of Bradford's reagent and $140 \mu \mathrm{l}$ of distilled water. Absorbance was measured at $595 \mathrm{~nm}$.

\subsubsection{Sodium Dodecyl Sulphate-Polyacrylamide Gel Electrophoresis (SDS-PAGE)}

SDS-PAGE analysis was used to determine the molecular weight of the tyrosinases. A $5 \%$ stacking gel and $12.5 \%$ separating gel was used for the optimal separation of the proteins of interest. The gels were poured according to the manufacturer's instructions for the BIO-RAD PROTEAN mini-gel system. $20 \mu \mathrm{l}$ of each tyrosinase sample (in duplicate) was mixed with $5 \mu \mathrm{l}$ of $5 x$ sample loading buffer containing dithiothreitol (DTT) [3.1 ml $1 \mathrm{M}$ Tris- $\mathrm{HCl}(\mathrm{pH} 6.8), 5 \mathrm{ml}$ glycerol, $0.5 \mathrm{ml} \mathrm{1 \% (w/v)} \mathrm{bromophenol} \mathrm{blue,} 5 \mathrm{mM}$ DTT and $1.4 \mathrm{ml}$ water]. The samples were boiled for $5 \mathrm{~min}$ prior to loading and $10 \mu \mathrm{l}$ of the Spectra multicolour broad range protein ladder (Fermentas) was loaded onto the gel. The gel was run at $100 \mathrm{~V}$ in electrophoresis buffer $[3.0 \mathrm{~g}$ Tris (25 mM), $14.4 \mathrm{~g}$ glycine (192 mM) and $1 \mathrm{~g}$ SDS in 1 litre water; $\mathrm{pH}$ 8.8]. The gel was stained with pre-made Thermo Scientific PageBlue protein staining solution overnight at $22^{\circ} \mathrm{C}$ on a rocking shaker. Excess stain was removed by washing the gels with distilled water for $10 \mathrm{~min}$.

\subsection{Characterisation of Partially Purified Tyrosinases}

All characterisation studies were performed using the partially purified tyrosinases, SPRTyr and CZA14Tyr. 


\subsubsection{Optimum $\mathrm{pH}$ and Substrate Range}

The substrate range of the two tyrosinases and the optimal $\mathrm{pH}$ for the oxidation of these substrates were determined. $50 \mathrm{mM}$ sodium acetate buffers (pH 3-5.5 in 0.5 increments), $50 \mathrm{mM}$ potassium phosphate buffers ( $\mathrm{pH}$ 6-7.5 in 0.5 increments) and $50 \mathrm{mM}$ Tris-HCl buffers $(\mathrm{pH}$ 8-10 in 0.5 increments) were used to determine the optimal $\mathrm{pH}$ for substrate oxidation. The following substrates were tested at a final concentration of $1 \mathrm{mM}$ : 2,2'-azino-bis(3-ethylbenzothiazoline-6sulphonic acid) (ABTS), 2,4-dichlorophenol (2,4-DCP), 2,6-dimethoxyphenol (2,6-DMP), 3hydroxyanthranilic acid (3-HAA), 4-methylcatechol, 4-tert-butylcatechol (4-TBC), caffeic acid, catechol, guaiacol, L-DOPA, L-tyrosine, o-aminophenol, p-cresol, phenol, pyrogallol, resorcinol and syringaldazine (SGZ). Oxidation of the monophenols L-tyrosine and p-cresol were also monitored in the presence of $1 \mu \mathrm{M}$ L-DOPA. Supplementary Table S1 summarises the conditions under which the enzyme activity was determined.

\subsubsection{Optimum Temperature}

The optimum temperature for the oxidation of L-DOPA was determined using the colourimetric assay as described before. The oxidation of the substrate at different temperatures was monitored at $475 \mathrm{~nm}$ using a PerkinElmer UV/Vis spectrophotometer Lambda 25 with a PTP-6+6 Peltier system for temperature control. The assay was performed at $5-60^{\circ} \mathrm{C}$ in 5 degree increments.

\subsubsection{Temperature Stability}

The temperature stability of the two enzymes was determined through incubation of the enzymes in a Corning LSE ${ }^{\mathrm{TM}}$ digital dry bath at $30^{\circ} \mathrm{C}, 40^{\circ} \mathrm{C}, 50^{\circ} \mathrm{C}$ and $60^{\circ} \mathrm{C}$. Triplicate samples were removed after $10 \mathrm{~min}, 20 \mathrm{~min}, 30 \mathrm{~min}$ and $60 \mathrm{~min}$, and immediately cooled on ice. The untreated samples stored at $4^{\circ} \mathrm{C}$ were used as reference samples. All samples were tested for their ability to oxidise L-DOPA at ambient temperature $\left(22 \pm 2^{\circ} \mathrm{C}\right)$. 


\subsection{4 pH Stability}

Equal amounts of each enzyme and $100 \mathrm{mM}$ buffer solutions were mixed, and incubated at $4^{\circ} \mathrm{C}$ for $24 \mathrm{~h}$. The buffers used were sodium acetate ( $\mathrm{pH}$ 3-5.5 in 0.5 increments), potassium phosphate ( $\mathrm{pH}$ 6-7.5 in 0.5 increments) and Tris- $\mathrm{HCl}(\mathrm{pH} 8-10$ in 0.5 increments). Activity was determined using the standard L-DOPA assay.

\subsubsection{Effect of Inhibitors, Reducing Agents and Metals}

The following compounds were tested to determine their effect on the ability of the two enzymes to oxidize L-DOPA: EDTA, L-ascorbic acid, L-cysteine, $\mathrm{NaCl}, p$-arbutin, SDS and sodium metabisulphite (concentrations ranged from 0.01 to $50 \mathrm{mM}$ ). In addition, the effect of the following metals was also determined: $\mathrm{Ca}^{2+}, \mathrm{Co}^{2+}, \mathrm{Cu}^{2+}, \mathrm{Fe}^{2+}, \mathrm{Mg}^{2+}, \mathrm{Mn}^{2+}$ and $\mathrm{Zn}^{2+}$ (concentrations ranged from 0.1 to $5 \mathrm{mM})$.

\subsubsection{Effect of Organic Solvents on Enzyme Activity}

The ability of the enzymes to oxidize L-DOPA in the presence of water-miscible organic solvents [2-propanol, acetone, acetonitrile, dimethylsulfoxide (DMSO), ethanol and methanol] was tested. Organic solvent was added to the L-DOPA/buffer mix immediately prior to performing the assay (final solvent concentrations ranged from 10 to $50 \%$, v/v). The oxidation of L-DOPA in the absence of organic solvent was used as the reference control.

To determine the stability of the enzymes in the presence of organic solvents, the enzymes were incubated at $4^{\circ} \mathrm{C}$ for $20 \mathrm{~h}$ in the presence of different concentrations of water-miscible organic solvents (same as above). Activity was determined using the standard L-DOPA assay and tyrosinase samples not incubated in organic solvents used as reference controls.

\subsubsection{Kinetics}

The kinetic parameters, $V_{\max }, K_{\mathrm{m}}$ and $k_{\mathrm{cat}}$, were determined for the oxidation of L-DOPA and $p$ cresol. Varying concentrations of the substrates were used (1-10 $\mathrm{mM})$ while maintaining a 
standard concentration of the tyrosinases $(1 \mathrm{U} / \mathrm{ml})$. Assays were performed at $22^{\circ} \mathrm{C}$ using a PerkinElmer UV/Vis, temperature-controlled spectrophotometer Lambda 25.

\subsection{Genomic DNA Isolation, Genome Sequencing and Annotation}

Genomic DNA was isolated from both bacterial strains using the method described by Mandel and Marmur [18]. DNA concentration was determined using a Qubit@ Fluorometer (Invitrogen). Sequencing libraries were prepared using the Roche 454 Titanium Rapid Library sequencing and Lib-L emulsion PCR kits. The integrity of the sequencing libraries was determined by Agilent Bioanalyser DNA 2100 chip. Libraries were sequenced on a Roche 454 GS Junior to a coverage of 20x. Both genomes were annotated using the online server, RAST version 4.0 (Rapid Annotation using Subsystem Technology) [19].

\subsubsection{Tyrosinase Sequence Analyses}

Tyrosinase sequences (MelC2) identified from the genome sequences were analysed using the program, DNAMAN version 4.13 (Lynnon Biosoft) for the prediction of amino acid content, MW and pl. The sequences were also analysed by protein BLAST [20] to identify related tyrosinase sequences. The MelC1 sequences were submitted to the TatP 1.0 server [21] to determine whether the signal peptides for export via the TAT pathway were present.

\subsection{Application of the Tyrosinases: Cross-Linking Reactions}

For the cross-linking experiments, the following reagents were prepared: $1.875 \mathrm{mg} / \mathrm{ml}$ target protein in sterile $\mathrm{dH}_{2} \mathrm{O} ; 10 \mathrm{mM}$ L-tyrosine in $50 \mathrm{mM}$ potassium phosphate buffer, $\mathrm{pH} 6.5 ; 10 \mathrm{mM} \mathrm{L-}$ DOPA in $50 \mathrm{mM}$ potassium phosphate buffer, $\mathrm{pH}$ 6.5; and a mixture of $10 \mathrm{mM}$ L-tyrosine and 10 mM L-DOPA (L-tyrosine/L-DOPA) in $50 \mathrm{mM}$ potassium phosphate buffer, $\mathrm{pH}$ 6.5. The target proteins tested were: BSA, casein, gelatine, horse heart cytochrome $c$ and horse myoglobin.

The following reactions were prepared for each target protein with each tyrosinase: 1) target protein only; 2) target protein + enzyme; 3) target protein + enzyme + L-tyrosine; 4) target protein 
+ enzyme + L-DOPA; and 5) target protein + enzyme + L-tyrosine/L-DOPA. Final reaction volumes were $500 \mu \mathrm{l}$ (made up with buffer) and the final concentrations in the reaction vessels were: 0.75 $\mathrm{mg} / \mathrm{ml}$ target protein, $1 \mathrm{mM}$ L-tyrosine, $1 \mathrm{mM} \mathrm{L-DOPA}$ and $1 \mathrm{U} / \mathrm{ml}$ enzyme.

The reactions were incubated at room temperature $\left(22 \pm 2^{\circ} \mathrm{C}\right)$ for $24 \mathrm{~h}$ on a Labnet LabRoller II, at $20 \mathrm{rpm} .20 \mu \mathrm{l}$ of each reaction was mixed with $5 \mu \mathrm{l} 5 \mathrm{x}$ sample loading buffer containing $1 \mathrm{mM}$ DTT. The samples (except for the horse heart cytochrome $c$ and horse myoglobin samples) were boiled for $10 \mathrm{~min}$ and centrifuged prior to loading onto an SDS-polyacrylamide gel (5\% stacking gel, $12.5 \%$ separating gel). A pre-stained protein ladder was included for comparative purposes. The gels were stained with the pre-made Thermo Scientific PageBlue protein staining solution overnight and washed with distilled water to visualise the bands. The gels with the horse heart cytochrome $c$ and horse myoglobin cross-linking experiment samples were not stained with the PageBlue Staining solution, but were stained with an o-dianisidine solution. Directly after electrophoresis, the gels were rinsed for $10 \mathrm{~min}$ with distilled water followed by a 10 min wash with a $10 \%(\mathrm{v} / \mathrm{v})$ trichloroacetic acid solution. The gels were rinsed with distilled water for two 10 min washes and finally stained with an o-dianisidine solution [50 mM sodium citrate buffer, $\mathrm{pH}$ 4.4, $0.7 \%(\mathrm{v} / \mathrm{v})$ hydrogen peroxide and $1 \mathrm{mg} / \mathrm{ml}$ o-dianisidine] [2].

\section{Results}

\subsection{Screening for Tyrosinase Activity: Solid Media}

Melanin production was clearly visible for the two test strains and the control strain. For all three strains, the most extensive melanin production occurred on DSMZ medium \#553 and the MPPM agar media (Fig. 1). Both strains were also positive for melanin production on ISP6 and ISP7 agar plates (greater production on ISP6 agar).

\subsection{Partial Purification of the Tyrosinases}

A yield of $11.5 \%$ (purification fold of 11.84 ) and $24.6 \%$ (purification fold of 5.16 ) was obtained for the SPRTyr and CZA14Tyr, respectively (Table 1). The production of SPRTyr was variable, with a 
a

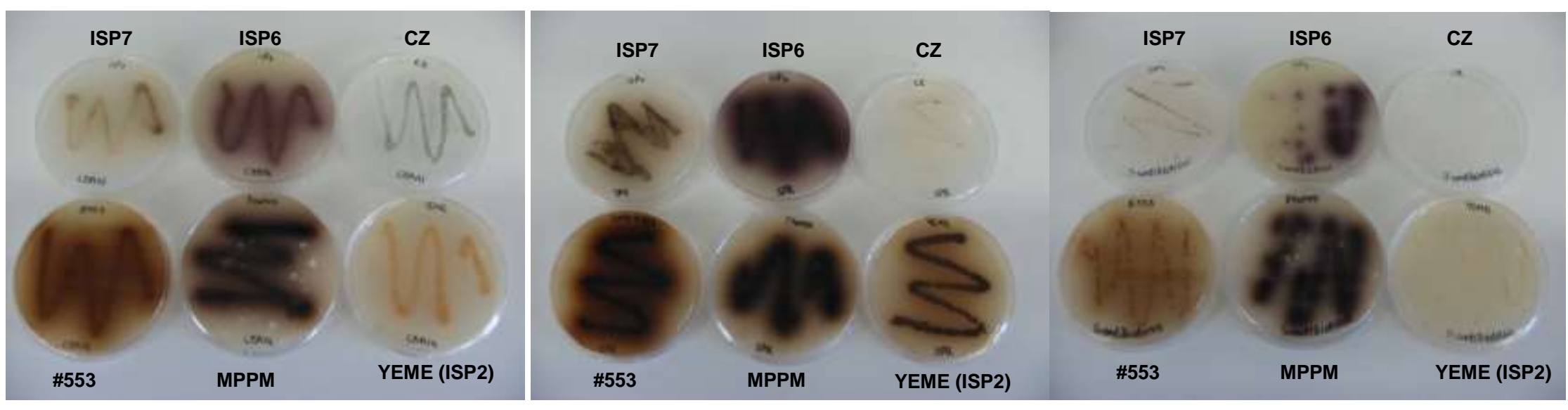

Fig. 1: Agar plate screening for melanin production on various agar media (Top row: ISP7, ISP6, CZ; Bottom row: DSMZ medium \#553, MPPM, YEME). a: S. pharetrae CZA14 ${ }^{\top}$; b: S. polyantibioticus SPR ${ }^{\top}$; and c: S. antibioticus (positive control). 
Table 1: Purification of SPRTyr and CZA14Tyr: ammonium sulphate precipitation and anion exchange chromatography. Enzyme activity was determined using the standard L-DOPA assay and protein concentration was determined using the Bradford's assay.

\begin{tabular}{|l|l|l|l|l|l|}
\hline Sample & $\begin{array}{l}\text { Total } \\
\text { activity } \\
(\mathbf{U})\end{array}$ & $\begin{array}{l}\text { Total } \\
\text { protein } \\
(\mathbf{m g})\end{array}$ & $\begin{array}{l}\text { Specific } \\
\text { activity } \\
(\mathbf{U} / \mathbf{m g})\end{array}$ & $\begin{array}{l}\text { Purification } \\
\text { fold }\end{array}$ & $\begin{array}{l}\text { Yield } \\
(\%)\end{array}$ \\
\hline $\begin{array}{l}\text { S. polyantibioticus SPR } \\
\text { culture filtrate }\end{array}$ & 1256 & 624 & 2.01 & 1 & 100 \\
\hline $\begin{array}{l}\text { After 40\% ammonium } \\
\text { sulphate precipitation }\end{array}$ & 801 & 523.8 & 1.53 & 0.76 & 63.8 \\
\hline After anion exchange & 144 & 4.26 & 23.80 & 11.84 & 11.5 \\
\hline & & & & 1 & 100 \\
\hline $\begin{array}{l}\text { S. pharetrae CZA14 } \\
\text { culture filtrate }\end{array}$ & 1246 & 426.41 & 2.92 & 1.43 & 123.2 \\
\hline $\begin{array}{l}\text { After 40\% ammonium } \\
\text { sulphate precipitation }\end{array}$ & 1535 & 368.57 & 4.17 & & 24.6 \\
\hline After anion exchange & 306.88 & 20.36 & 15.07 & 5.16 & \\
\hline
\end{tabular}

shift in the optimum growth temperature observed during the course of this study (optimal growth and production was initially at $30^{\circ} \mathrm{C}$, but later changed to $22^{\circ} \mathrm{C}$ ). The yield was consistently higher and reproducible for the production of CZA14Tyr. A maximum level of $5.32 \mathrm{mg} / \mathrm{L}$ and $16.97 \mathrm{mg} / \mathrm{L}$ tyrosinase was purified from the culture filtrates for S. polyantibioticus $\mathrm{SPR}^{\top}$ and $S$. pharetrae CZA14 ${ }^{\top}$, respectively.

\subsection{SDS-PAGE Analysis}

Using the protein ladder, a standard curve was generated to determine the size of the two tyrosinases (data not shown). Both samples had two major bands, one at $43.7 \mathrm{kDa}$, and a second band at $30.5 \mathrm{kDa}$ and $32.6 \mathrm{kDa}$ for S. polyantibioticus $\mathrm{SPR}^{\top}$ and S. pharetrae CZA14 ${ }^{\top}$, respectively (Fig. 2). 


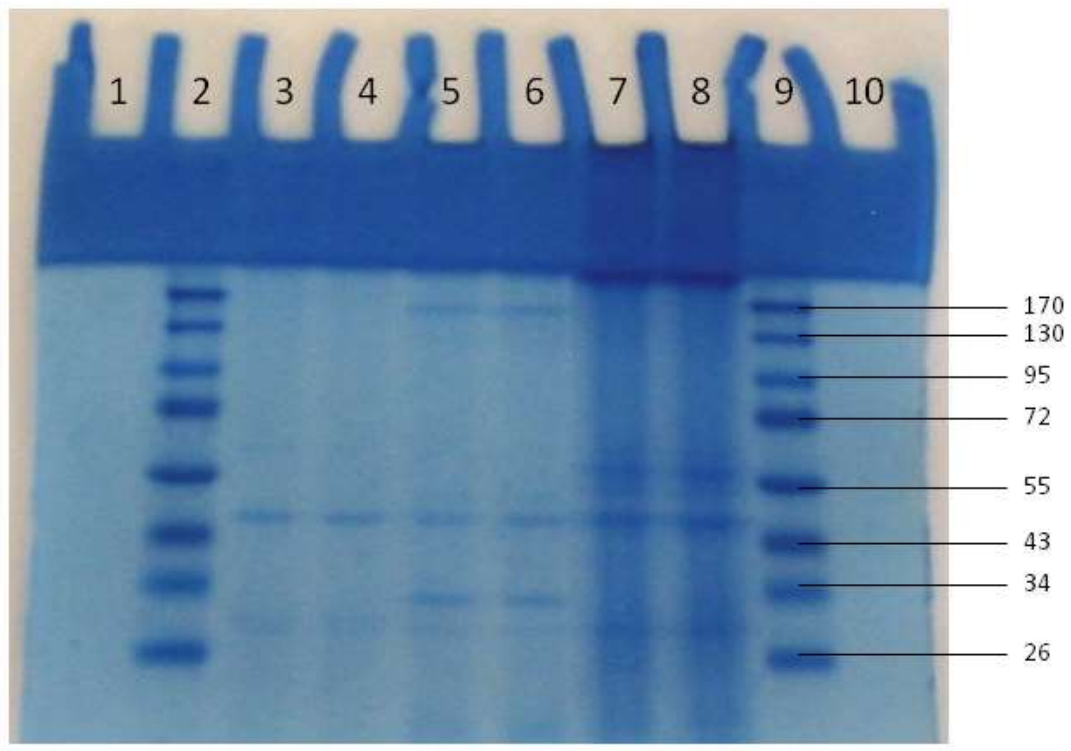

Fig. 2: SDS-PAGE analysis of the tyrosinases used in this study. Lanes 2 and 9: Protein ladder; Lanes 3 and 4: SPRTyr; Lanes 5 and 6: CZA14Tyr (partially purified); and Lanes 7 and 8: Crude extract from S. antibioticus (positive control used in this study).

\subsection{Characterisation of Partially Purified Tyrosinases}

\subsubsection{Optimum $\mathrm{pH}$ and Substrate Range}

Typical tyrosinase substrates were oxidized by both tyrosinases, whereas typical peroxidase substrates (2,4-DCP, phenol; in the presence and absence of $\left.\mathrm{H}_{2} \mathrm{O}_{2}\right)$ and laccase substrates $(2,6-$ DMP, ABTS, guaiacol, resorcinol, syringaldazine) were not oxidized (Table 2). A slight difference in specific activity and optimal pH for oxidation of the substrates was observed between the two tyrosinases. For the oxidation of the monophenols, L-tyrosine and p-cresol, the effect of the addition of $10 \mu \mathrm{M}$ L-DOPA was determined: for the oxidation of $p$-cresol, the specific activity doubled, whereas for the oxidation of L-tyrosine, little variation in the specific activity was observed. In addition, the monophenolase:diphenolase ratio was determined for both monophenol/diphenol combinations: the L-tyrosine:L-DOPA ratio was $0.059(0.058$ when $10 \mu \mathrm{M}$ LDOPA was added to the L-tyrosine) for the SPRTyr and 0.049 (0.051 with $10 \mu \mathrm{M} \mathrm{L-DOPA)} \mathrm{for}$ CZA14Tyr; and the $p$-cresol: L-DOPA ratio was 0.072 (0.143 with $10 \mu \mathrm{M} \mathrm{L-DOPA)} \mathrm{for} \mathrm{SPRTyr} \mathrm{and}$ 
Table 2: The specific activity determined for SPRTyr and CZA14Tyr using different substrates and the optimal $\mathrm{pH}$ for their oxidation; no activity was detected using 2,4-DCP, 2,6-DMP, ABTS, guaiacol, phenol, resorcinol and syringaldazine (mean $\pm S E M ; n=3$ ).

\begin{tabular}{|c|c|c|c|}
\hline Tyrosinase & Substrate & $\begin{array}{l}\text { Optimal pH for } \\
\text { oxidation }\end{array}$ & $\begin{array}{l}\text { Specific activity } \\
\text { (U/mg) }\end{array}$ \\
\hline SPRTyr & \multirow[t]{2}{*}{ 3-HAA } & 8.5 & $0.37 \pm 0.04$ \\
\hline CZA14Tyr & & 9.5 & $0.18 \pm 0.02$ \\
\hline SPRTyr & \multirow[t]{2}{*}{ 4-methylcatechol } & 5.5 & $20.00 \pm 4.45$ \\
\hline CZA14Tyr & & 5.5 & $16.80 \pm 1.35$ \\
\hline SPRTyr & \multirow[t]{2}{*}{ 4-TBC (400 nm) } & 7.5 & $29.73 \pm 2.73$ \\
\hline CZA14Tyr & & 7.0 & $27.02 \pm 0.92$ \\
\hline SPRTyr & \multirow[t]{2}{*}{ 4-TBC (475 nm) } & 8.0 & $0.82 \pm 0.05$ \\
\hline CZA14Tyr & & 8.0 & $0.68 \pm 0.06$ \\
\hline SPRTyr & \multirow[t]{2}{*}{ Caffeic acid } & 5.5 & $6.67 \pm 0.90$ \\
\hline CZA14Tyr & & 5.5 & $6.15 \pm 0.73$ \\
\hline SPRTyr & \multirow[t]{2}{*}{ Catechol } & 7.0 & $19.27 \pm 0.25$ \\
\hline CZA14Tyr & & 7.0 & $24.37 \pm 0.39$ \\
\hline SPRTyr & \multirow[t]{2}{*}{ L-DOPA } & 5.5 & $14.09 \pm 0.10$ \\
\hline CZA14Tyr & & 5.5 & $16.00 \pm 0.54$ \\
\hline SPRTyr & \multirow[t]{2}{*}{ L-tyrosine } & 8.0 & $0.83 \pm 0.04$ \\
\hline CZA14Tyr & & 8.0 & $0.78 \pm 0.01$ \\
\hline SPRTyr & \multirow[t]{2}{*}{ L-tyrosine + $10 \mu \mathrm{M}$ L-DOPA } & 9.0 & $0.81 \pm 0.03$ \\
\hline CZA14Tyr & & 9.0 & $0.62 \pm 0.02$ \\
\hline SPRTyr & \multirow[t]{2}{*}{ o-aminophenol } & 9.0 & $0.42 \pm 0.01$ \\
\hline CZA14Tyr & & 9.0 & $0.25 \pm 0.01$ \\
\hline SPRTyr & \multirow[t]{2}{*}{$p$-cresol } & 8.0 & $1.01 \pm 0.02$ \\
\hline CZA14Tyr & & 8.0 & $0.77 \pm 0.03$ \\
\hline SPRTyr & \multirow[t]{2}{*}{$p$-cresol + $10 \mu \mathrm{M}$ L-DOPA } & 8.0 & $2.02 \pm 0.15$ \\
\hline CZA14Tyr & & 8.0 & $1.57 \pm 0.06$ \\
\hline SPRTyr & \multirow[t]{2}{*}{ Pyrogallol } & 7.0 & $1.30 \pm 0.15$ \\
\hline CZA14Tyr & & 7.0 & $1.35 \pm 0.02$ \\
\hline
\end{tabular}

0.048 (0.098 with $10 \mu \mathrm{M}$ L-DOPA) for CZA14Tyr. For the oxidation of the monophenols, a lagperiod of more than 10 min was observed for both enzymes before the o-hydroxylation reactions occurred. 
a

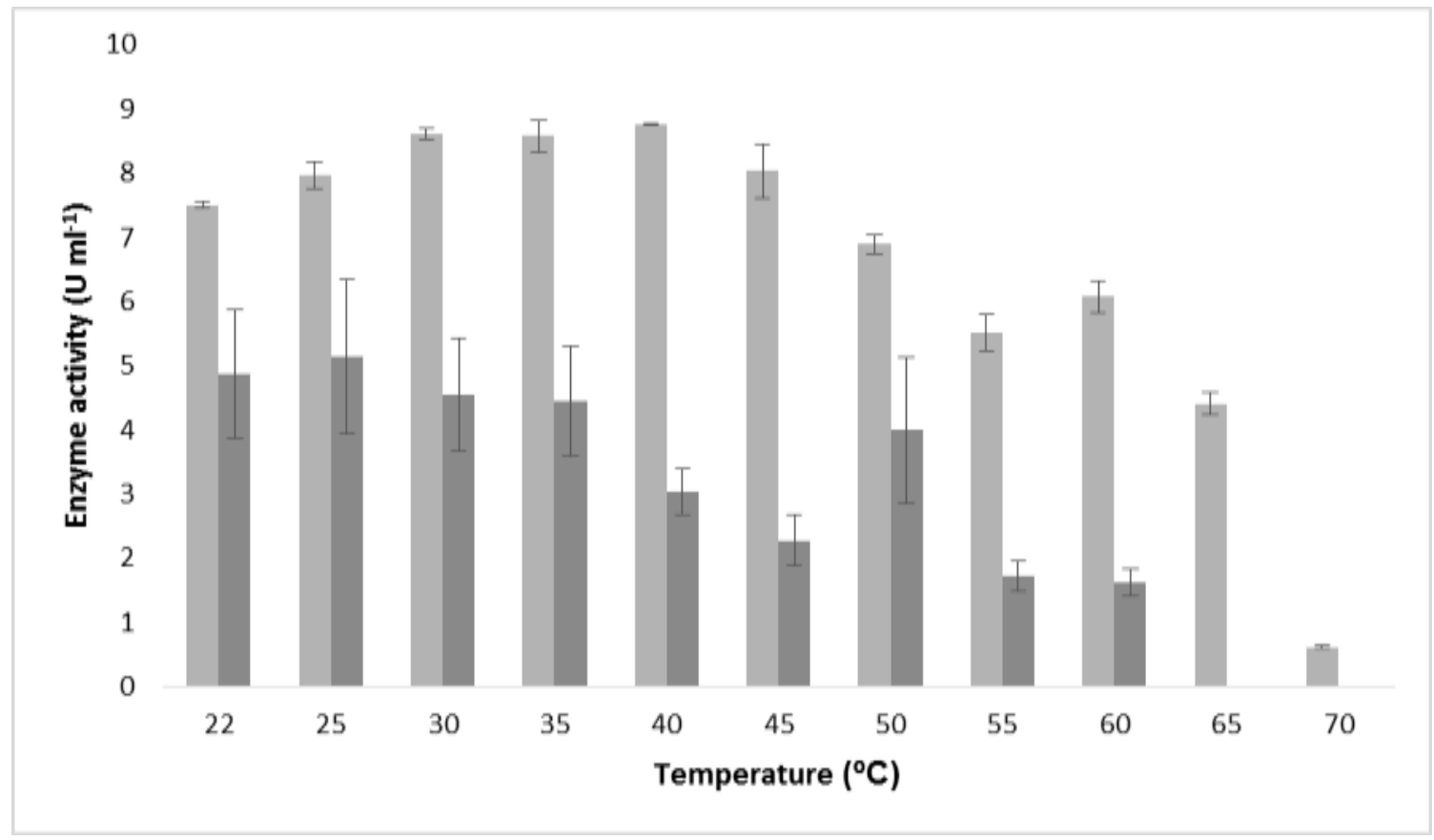

b

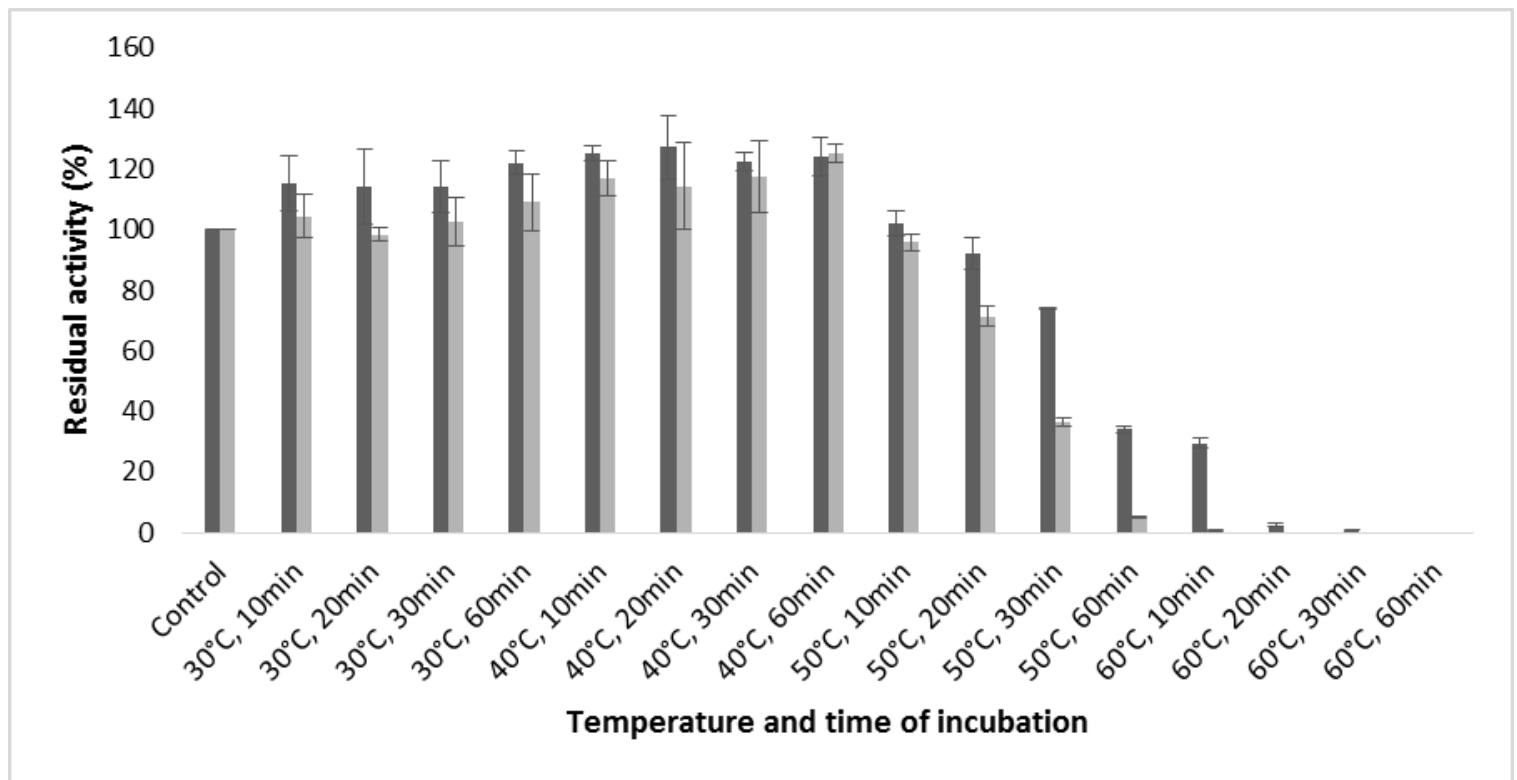

Fig. 3: a The effect of temperature on the oxidation of $10 \mathrm{mM}$ L-DOPA for CZA14Tyr $(\square)$ and SPRTyr $(\square)$. b Thermostability of CZA14Tyr ( $\square)$ and SPRTyr $(\square)$ when incubated at different temperatures for 10, 20, 30 and 60 min. Activity was measured using the standard L-DOPA assay. 


\subsubsection{Optimum Temperature and Temperature Stability}

For the oxidation of L-DOPA (10 mM), CZA14Tyr was able to oxidise the substrate optimally across a range of temperatures: $30-40^{\circ} \mathrm{C}$ with a second peak at $60^{\circ} \mathrm{C}$ (Fig. 3a). In contrast, SPRTyr oxidised L-DOPA optimally around $22-35^{\circ} \mathrm{C}$, with a second peak at $50^{\circ} \mathrm{C}$. The tyrosinases were stable for $1 \mathrm{~h}$ up to $40^{\circ} \mathrm{C}$, but a decline in activity was observed for both enzymes when incubated at $50^{\circ} \mathrm{C}$ (Fig. 3b). CZA14Tyr retained more activity than SPRTyr, with $33.96 \pm 1.05 \%$ residual activity compared to $4.90 \pm 0.26 \%$ residual activity for SPRTyr after $1 \mathrm{~h}$ of incubation at $50^{\circ} \mathrm{C}$. CZA14Tyr showed a residual activity of $29.50 \pm 1.72 \%(0.53 \pm 0.14 \%$ for SPRTyr) after 10 min incubation at $60^{\circ} \mathrm{C}$, but rapidly lost activity after 20 min of incubation at $60^{\circ} \mathrm{C}(2.46 \pm 0.40 \%$ residual activity $)$.

\subsection{3 pH Stability}

SPRTyr retained $100 \%$ of its activity after $24 \mathrm{~h}$ of incubation in the presence of buffers ranging from $\mathrm{pH} 5-10$. Below $\mathrm{pH} 5.0$, the residual enzyme activity declined from $70.75 \pm 5.51 \%$ at $\mathrm{pH} 4.5$ to $13.90 \pm 1.93 \%$ at $\mathrm{pH} 4.0$ and $1.54 \pm 0.74 \%$ at $\mathrm{pH} 3.5$. Total loss of activity occurred at $\mathrm{pH} 3.0$. CZA14Tyr was more sensitive than SPRTyr to lower $\mathrm{pH}$ levels, with $100 \%$ residual activity detected in the presence of buffers ranging from $\mathrm{pH} 6.5-10$ and a total loss of activity observed for samples incubated in buffers below pH $5.0(\mathrm{pH}$ 6.0: $96.98 \pm 1.67 \%$; $\mathrm{pH}$ 5.5: $93.29 \pm 3.61 \%$; and $\mathrm{pH} 5.0: 29.01 \pm 5.16 \%)$.

\subsubsection{Effect of Reducing Agents, Inhibitors and Metals}

Both tyrosinases were strongly inhibited by the reducing agents tested in this study (L-ascorbic acid, L-cysteine and sodium metabisulphite; Table 3). Total inhibition of the CZA14Tyr occurred in the presence of $0.5 \mathrm{mM}$ L-cysteine, $0.2 \mathrm{mM}$ sodium metabisulphite and $1 \mathrm{mM} \mathrm{L-ascorbic} \mathrm{acid,}$ while the SPRTyr was totally inhibited by $1 \mathrm{mM}$ L-cysteine, $0.5 \mathrm{mM}$ sodium metabisulphite and 2 mM L-ascorbic acid. Minimal effect was observed with $\mathrm{NaCl}$ (> $80 \%$ residual activity for both enzymes at $50 \mathrm{mM}$ ), as well as SDS and $p$-arbutin (> $90 \%$ residual activity for both enzymes at 
Table 3: Effect of inhibitors, reducing agents and metals on the activity of the SPR and CZA14 tyrosinases.

\begin{tabular}{|c|c|c|c|}
\hline $\begin{array}{l}\text { Inhibitor, reducing } \\
\text { agent or metal }\end{array}$ & $\begin{array}{l}\text { Concentration } \\
\text { tested }(\mathrm{mM})\end{array}$ & $\begin{array}{l}\text { Residual activity (\%) - } \\
\text { SPRTyr }\end{array}$ & $\begin{array}{l}\text { Residual activity (\%) - } \\
\text { CZA14Tyr }\end{array}$ \\
\hline Arbutin & 50 & $96.47 \pm 1.72$ & $96.08 \pm 0.59$ \\
\hline EDTA & $\begin{array}{l}1 \\
2 \\
5 \\
10 \\
25 \\
50\end{array}$ & $\begin{array}{l}78.71 \pm 14.36 \\
79.89 \pm 5.30 \\
77.03 \pm 13.32 \\
82.03 \pm 7.91 \\
89.38 \pm 8.68 \\
82.56 \pm 7.77\end{array}$ & $\begin{array}{l}81.16 \pm 0.46 \\
80.57 \pm 1.97 \\
79.14 \pm 0.37 \\
78.08 \pm 1.76 \\
69.67 \pm 1.02 \\
48.50 \pm 4.12\end{array}$ \\
\hline L-ascorbic acid & $\begin{array}{l}0.2 \\
0.5 \\
1 \\
2\end{array}$ & $\begin{array}{l}98.01 \pm 3.28 \\
60.59 \pm 10.35 \\
19.54 \pm 4.19 \\
0\end{array}$ & $\begin{array}{l}96.98 \pm 3.53 \\
53.10 \pm 2.24 \\
0 \\
0\end{array}$ \\
\hline L-cysteine & $\begin{array}{l}0.05 \\
0.1 \\
0.2 \\
0.5 \\
1\end{array}$ & $\begin{array}{l}91.66 \pm 2.14 \\
88.33 \pm 5.10 \\
71.96 \pm 9.90 \\
23.71 \pm 2.49 \\
0\end{array}$ & $\begin{array}{l}95.59 \pm 1.30 \\
88.71 \pm 0.55 \\
55.86 \pm 1.57 \\
0 \\
0\end{array}$ \\
\hline $\mathrm{NaCl}$ & $\begin{array}{l}25 \\
50\end{array}$ & $\begin{array}{l}100.42 \pm 6.45 \\
89.38 \pm 7.20\end{array}$ & $\begin{array}{l}85.54 \pm 3.83 \\
81.18 \pm 0.87\end{array}$ \\
\hline SDS & 50 & $97.67 \pm 2.60$ & $117.0 \pm 3.41$ \\
\hline Sodium metabisulphite & $\begin{array}{l}0.02 \\
0.05 \\
0.1 \\
0.2 \\
0.5\end{array}$ & $\begin{array}{l}87.42 \pm 6.78 \\
76.08 \pm 13.81 \\
84.43 \pm 5.63 \\
63.14 \pm 5.63 \\
0\end{array}$ & $\begin{array}{l}95.58 \pm 1.60 \\
95.17 \pm 0.90 \\
64.52 \pm 1.02 \\
0 \\
0\end{array}$ \\
\hline $\mathrm{Ca}^{2+}$ & $0.1-5$ & $101.45 \pm 3.63$ & $99.48 \pm 8.00$ \\
\hline $\mathrm{Co}^{2+}$ & $\begin{array}{l}0.1-2 \\
5\end{array}$ & $\begin{array}{l}111.02 \pm 1.71 \\
78.37 \pm 0.49\end{array}$ & $\begin{array}{l}118.01 \pm 3.21 \\
100.56 \pm 1.69\end{array}$ \\
\hline $\mathrm{Cu}^{2+}$ & $\begin{array}{l}2 \\
5\end{array}$ & $\begin{array}{l}70.95 \pm 4.48 \\
36.23 \pm 2.98\end{array}$ & $\begin{array}{l}52.88 \pm 22.33 \\
33.27 \pm 1.86\end{array}$ \\
\hline $\mathrm{Fe}^{2+}$ & $\begin{array}{l}0.1-2 \\
5\end{array}$ & $\begin{array}{l}106.40 \pm 5.23 \\
100.27 \pm 5.39\end{array}$ & $\begin{array}{l}126.36 \pm 12.82 \\
0\end{array}$ \\
\hline $\mathrm{Mg}^{2+}$ & $0.1-5$ & $113.63 \pm 1.69$ & $109.19 \pm 5.56$ \\
\hline $\mathrm{Mn}^{2+}$ & $0.1-5$ & $106.17 \pm 1.70$ & $98.60 \pm 3.91$ \\
\hline $\mathrm{Zn}^{2+}$ & $\begin{array}{l}0.1-2 \\
5\end{array}$ & $\begin{array}{l}104.77 \pm 1.92 \\
110.13 \pm 4.47\end{array}$ & $\begin{array}{l}102.74 \pm 3.36 \\
29.79 \pm 1.55\end{array}$ \\
\hline
\end{tabular}


$50 \mathrm{mM}$ ). EDTA had a variable effect on the activity of SPRTyr, but inhibited CZA14Tyr, with a residual activity of $48.50 \pm 4.12 \%$ at $50 \mathrm{mM}$.

Tyrosinase activity was enhanced by $\mathrm{Ca}^{2+}, \mathrm{Mg}^{2+}$ and $\mathrm{Mn}^{2+}$. CZA14Tyr was unaffected at $5 \mathrm{mM}$ $\mathrm{Co}^{2+}$, while SPRTyr had a residual activity of $78.37 \pm 0.49 \%$. Increasing $\mathrm{Cu}^{2+}$ concentrations increased inhibition of both tyrosinases $\left(<40 \%\right.$ residual activity for both enzymes at $5 \mathrm{mM} \mathrm{Cu}^{2+}$;

Table 3). SPRTyr was unaffected by $5 \mathrm{mM} \mathrm{Fe}^{2+}$, while CZA14Tyr was completely inhibited. Similarly, SPRTyr was unaffected at $5 \mathrm{mM} \mathrm{Zn}^{2+}$, while only $29.79 \pm 1.55 \%$ residual activity was observed for CZA14Tyr.

\subsubsection{Effect of Organic Solvents on Enzyme Stability and Activity}

The stability of the two tyrosinases in the presence of water-miscible organic solvents was determined through incubation of the enzymes with varying concentrations of solvent for $20 \mathrm{~h}$. Both enzymes were strongly inhibited by $30 \%(\mathrm{v} / \mathrm{v})$ acetonitrile with $<15 \%$ residual activity detected (10.73 $\pm 1.31 \%$ for CZA14Tyr and $2.40 \pm 1.99 \%$ for SPRTyr) (Fig. 4). At lower acetonitrile concentrations (20\%, v/v), CZA14Tyr was more strongly inhibited than SPRTyr (47.20 $\pm 5.35 \%$ residual activity for CZA14Tyr and $71.71 \pm 5.57 \%$ residual activity for SPRTyr). Ethanol, acetone and 2-propanol showed strong inhibitory effects only at concentrations above $40 \%(\mathrm{v} / \mathrm{v})$. The SPRTyr was strongly inhibited in the presence of $40 \%(\mathrm{v} / \mathrm{v})$ methanol $(21.37 \pm 11.12 \%$ residual activity), while the CZA14Tyr exhibited $74.66 \pm 1.92 \%$ residual activity at $40 \%(\mathrm{v} / \mathrm{v})$ methanol and $17.64 \pm 3.79 \%$ at $50 \%(\mathrm{v} / \mathrm{v})$ methanol (SPRTyr completely inhibited at 50\%, v/v). Both enzymes were highly stable in the presence of $50 \%(\mathrm{v} / \mathrm{v})$ DMSO: $61.61 \pm 5.46 \%$ residual activity for SPRTyr and $60.80 \pm 4.40 \%$ residual activity for CZA14Tyr. At 10\% (v/v) of ethanol, methanol and 2-propanol, and 20\% (v/v) ethanol and methanol, an enhancing effect was observed for the SPRTyr.

Both enzymes were able to oxidise L-DOPA in the presence of the organic solvents tested (Fig. 5). More than $50 \%$ residual activity was observed for SPRTyr in the presence of $40 \%(\mathrm{v} / \mathrm{v})$ 
a

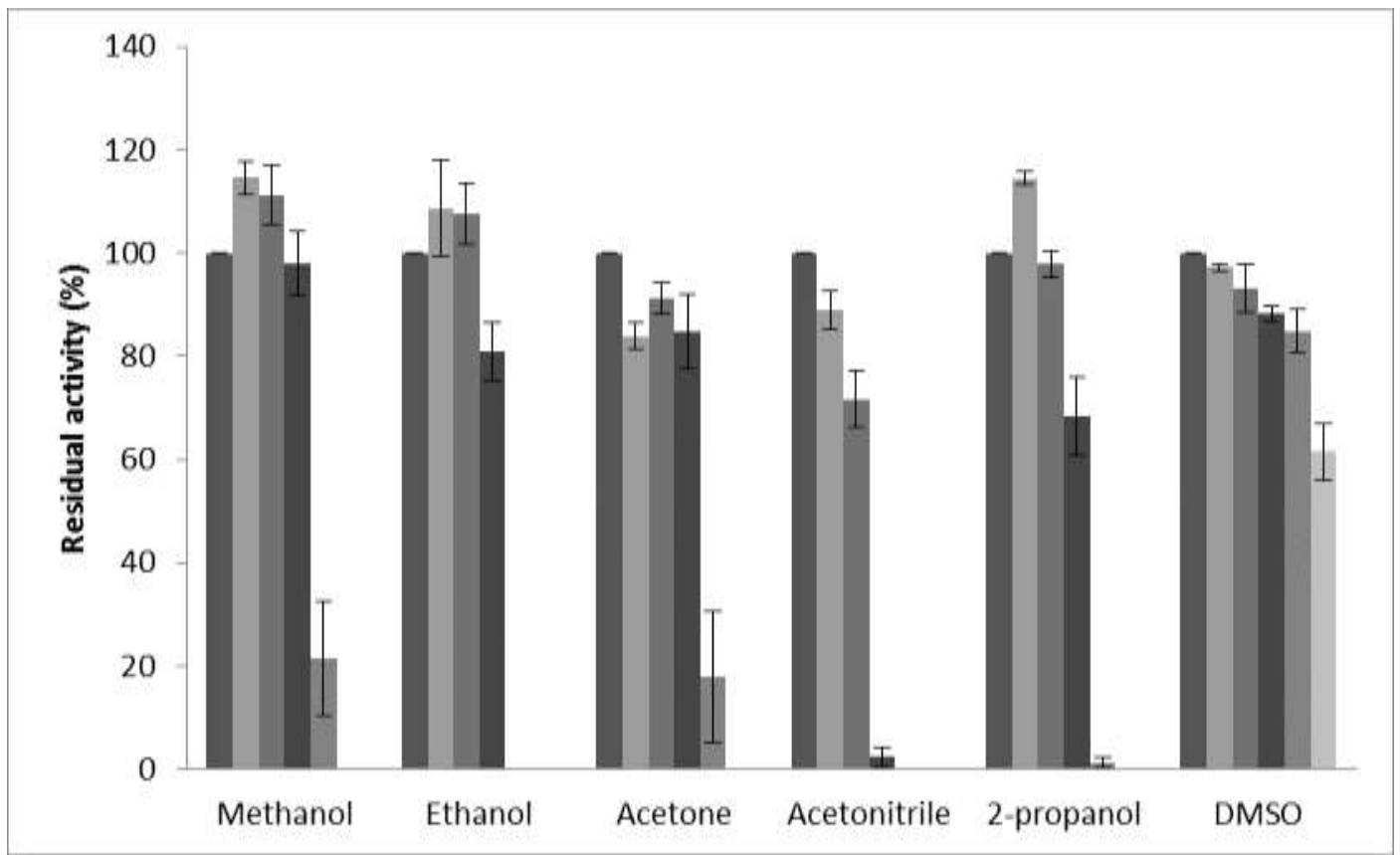

b

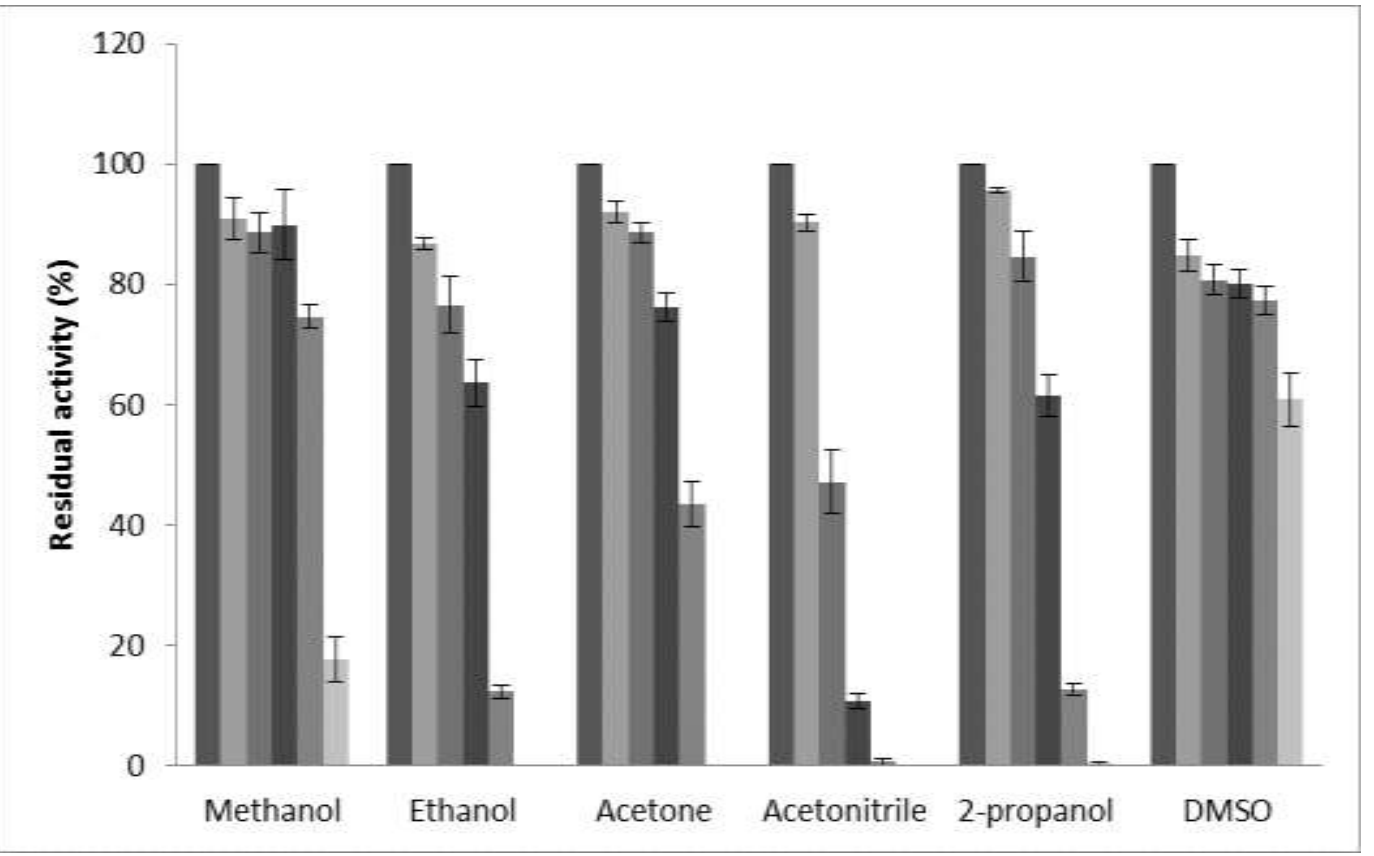

Fig. 4: The stability of the two tyrosinases, SPRTyr (a) and CZA14Tyr (b) incubated in the presence of $\square 0 \square 10 \square 20 \square 30-40$ and $\square 50 \%(\mathrm{v} / \mathrm{v})$ water-miscible organic solvents (incubated for $20 \mathrm{~h}$ at $4^{\circ} \mathrm{C}$ ). Residual activity was calculated compared to a sample incubated without any organic solvent present. Activity was determined using the standard L-DOPA assay. 
a

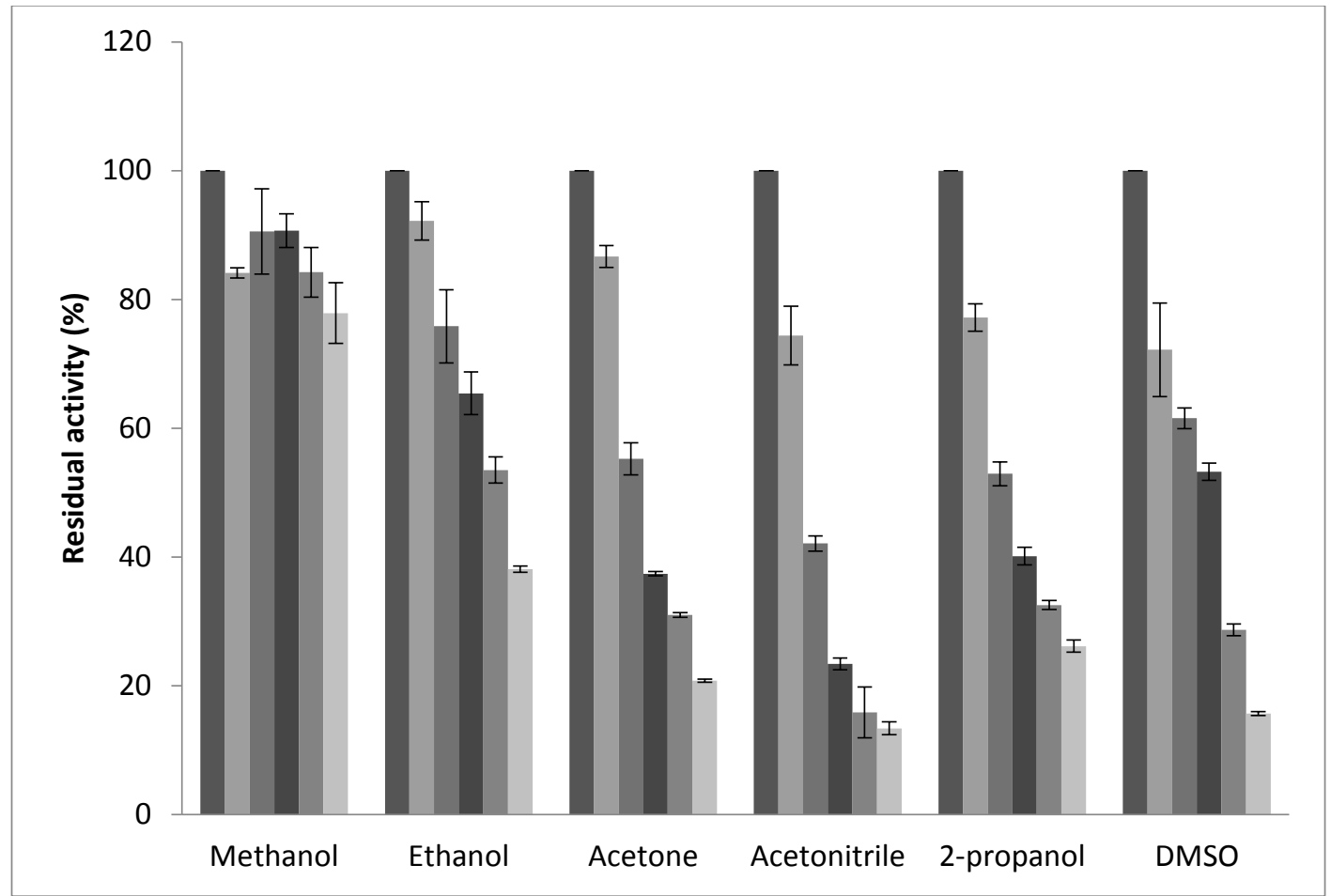

b

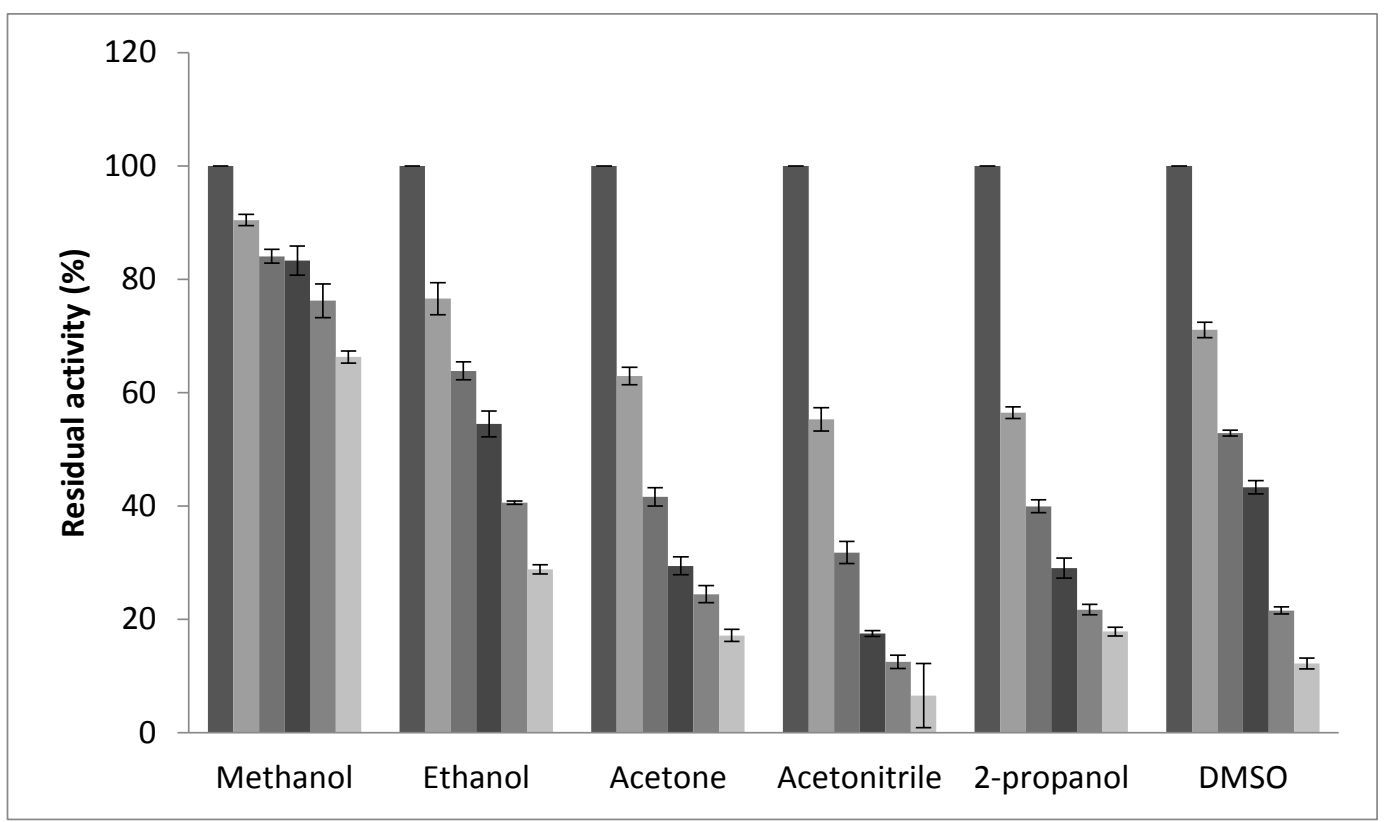

Fig. 5: The effect of organic solvents on the ability of the two tyrosinases, SPRTyr (a) and CZA14Tyr (b), to oxidise L-DOPA. Oxidation of L-DOPA was performed in the presence of $\square 0$ $10 \square 20 \square 30 \square 40$ and $\square 50 \%(\mathrm{v} / \mathrm{v})$ water-miscible organic solvents Residual activity was calculated compared to the oxidation of L-DOPA under standard conditions. 
ethanol, 20\% (v/v) acetone, 30\% (v/v) DMSO and 20\% (v/v) 2-propanol, and > 70\% residual activity in the presence of $10 \%(\mathrm{v} / \mathrm{v})$ acetonitrile and $50 \%(\mathrm{v} / \mathrm{v})$ methanol. For CZA14Tyr, > 50\% residual activity was observed in the presence of $30 \%(\mathrm{v} / \mathrm{v})$ ethanol, $10 \%(\mathrm{v} / \mathrm{v})$ acetone, $10 \%(\mathrm{v} / \mathrm{v})$ acetonitrile, $20 \%(\mathrm{v} / \mathrm{v})$ DMSO and $20 \%(\mathrm{v} / \mathrm{v})$ 2-propanol, while there was $>60 \%$ residual activity detected in the presence of $50 \%(\mathrm{v} / \mathrm{v})$ methanol.

\section{$3.5 \underline{\text { Kinetics }}$}

The kinetic parameters for the oxidation of $p$-cresol and L-DOPA were determined for both enzymes. CZA14Tyr has a higher $K_{\mathrm{m}}$ value for $p$-cresol $\left(K_{\mathrm{m}}=1.54 \pm 0.54 \mathrm{mM} ; V_{\max }=0.73 \pm 0.06\right.$ $\mu \mathrm{M} / \mathrm{min})$ and a lower $K_{\mathrm{m}}$ value for L-DOPA $\left(K_{\mathrm{m}}=1.79 \pm 0.86 \mathrm{mM} ; V_{\max }=163.67 \pm 24.01 \mu \mathrm{M} / \mathrm{min}\right)$ than SPRTyr ( $p$-cresol: $K_{\mathrm{m}}=0.66 \pm 0.20 \mathrm{mM}, V_{\max }=0.71 \pm 0.01 \mu \mathrm{M} / \mathrm{min}$; and L-DOPA: $K_{\mathrm{m}}=3.13$ $\left.\pm 0.28 \mathrm{mM}, V_{\max }=92.87 \pm 2.73 \mu \mathrm{M} / \mathrm{min}\right)$. Calculation of $k_{\text {cat }} / K_{\mathrm{m}}$ showed that SPRTyr has a greater specificity for $p$-cresol $\left(85.25 \mathrm{~s}^{-1} \mathrm{mM}^{-1} ; k_{\text {cat }}=56.27 \mathrm{~s}^{-1}\right)$ than CZA14Tyr $\left(15.01 \mathrm{~s}^{-1} \mathrm{mM}^{-1} ; k_{\text {cat }}=\right.$

$\left.23.11 \mathrm{~s}^{-1}\right)$. In contrast, CZA14Tyr has a greater specificity for L-DOPA with a $k_{\text {cat }} / K_{\mathrm{m}}$ of $2894.43 \mathrm{~s}^{-1}$ $\mathrm{mM}^{-1}\left(k_{\text {cat }}=5181.03 \mathrm{~s}^{-1}\right)$ compared to SPRTyr $\left(2351.40 \mathrm{~s}^{-1} \mathrm{mM}^{-1} ; k_{\text {cat }}=7359.84 \mathrm{~s}^{-1}\right)$.

\subsection{Sequence Analyses}

Genome sequence analysis revealed the presence of MelC1-MelC2 tyrosinase operons for both strains. BLAST analysis revealed that these operons are related to the extracellular streptomycete MelC1-MeIC2 tyrosinases typically described in literature. The MelC2 sequence from S. polyantibioticus SPR ${ }^{\top}$ (GenBank accession number: KR030067) showed 63\% sequence similarity to the tyrosinase from Streptomyces venezuelae ATCC10712 (YP_006880197), while the MelC2 from S. pharetrae CZA14 ${ }^{\top}$ (GenBank accession number: KR030068) showed 81\% sequence similarity to the tyrosinase from Streptomyces ascidiscabies 84-104 (WP_010358344). Multiple sequence alignment of selected tyrosinase sequences allowed for the confirmation of the presence of the histidine residues involved in the co-ordination of CuA and CuB (Supplementary Fig. S1). Analysis of the MelC2 sequence from S. polyantibioticus SPR ${ }^{\top}$ revealed the following: CuA signature sequence of $\mathrm{H}_{39}-\mathrm{X}(15)-\mathrm{H}_{55}-\mathrm{X}(8)-\mathrm{H}_{64}$ and a CuB signature sequence of $\mathrm{H}_{203}-\mathrm{X}(3)-$ 
$\mathrm{H}_{207}-\mathrm{X}(35)-\mathrm{H}_{243}$. The CuA signature sequence for the MelC2 sequence from S. pharetrae CZA14 ${ }^{\top}$ is the same as for S. polyantibioticus $\mathrm{SPR}^{\top}$, with the exception that the CuB signature sequence was found to be $\mathrm{H}_{200}-\mathrm{X}(3)-\mathrm{H}_{204}-\mathrm{X}(35)-\mathrm{H}_{240}$. In addition, an analysis of the MelC1 sequences (GenBank accession numbers: KR030065 and KR030066, for strains SPR ${ }^{\top}$ and CZA14 ${ }^{\top}$, respectively) from both strains using the online server, TatP 1.0, revealed the presence of the signal peptide sequence for the export of proteins via the TAT pathway (Supplementary Fig. S2).

Analysis of the MelC2 sequences, allowed for the prediction of the MW, length and $\mathrm{pl}$ of the tyrosinases. The extracellular MelC2 of S. polyantibioticus $\mathrm{SPR}^{\top}$ and S. pharetrae CZA14 ${ }^{\top}$ had similar molecular weights and characteristics: 292 aa, $33.76 \mathrm{kDa}$, pl of 9.92 for the MelC2 from S. polyantibioticus SPR ${ }^{\top}$; and 288 aa, $33.618 \mathrm{kDa}$, pl of 10.03 for the MelC2 from S. pharetrae CZA14 ${ }^{\top}$. The predicted MW and the observed MW from SDS-PAGE analysis (30.5 kDa and 32.6 $\mathrm{kDa}$ for S. polyantibioticus $\mathrm{SPR}^{\top}$ and S. pharetrae $\mathrm{CZA} 14^{\top}$, respectively) was within a similar range.

\subsection{Application of the Tyrosinases: Cross-Linking Reactions}

SPRTyr and CZA14Tyr were both able to cross-link the target proteins used in this study to various extents (Table 4). Cross-linking was observed by formation of a distinctive precipitate $n$ the reaction vessels (Supplementary Fig. S3a), which when viewed under a light microscope, was visible as an extensively cross-linked matrix (Supplementary Fig. S3b). This was confirmed by SDS-PAGE analyses where cross-linked proteins were visualised as high molecular weight bands. Both enzymes were able to cross-link gelatine (Supplementary Fig. S4a) and casein (Supplementary Fig. S4b) in the presence and absence of a phenolic compound. BSA was only partially cross-linked and required a $48 \mathrm{~h}$ incubation period; the cross-linking of this protein was only clearly visible in the sample containing both L-tyrosine and L-DOPA (Supplementary Fig. S4c). Partial cross-linking of horse heart cytochrome $c$ (Supplementary Fig. S5a) and horse myoglobin (Supplementary Fig. S5b) occurred in the absence of a phenolic compound. However, 
Table 4: A summary of the cross-linking ability of SPRTyr and CZA14Tyr when selected target proteins were used. The various target proteins, the reaction conditions and the reaction mechanisms are indicated. Phenolic compounds used in this study were L-DOPA and L-Tyrosine.

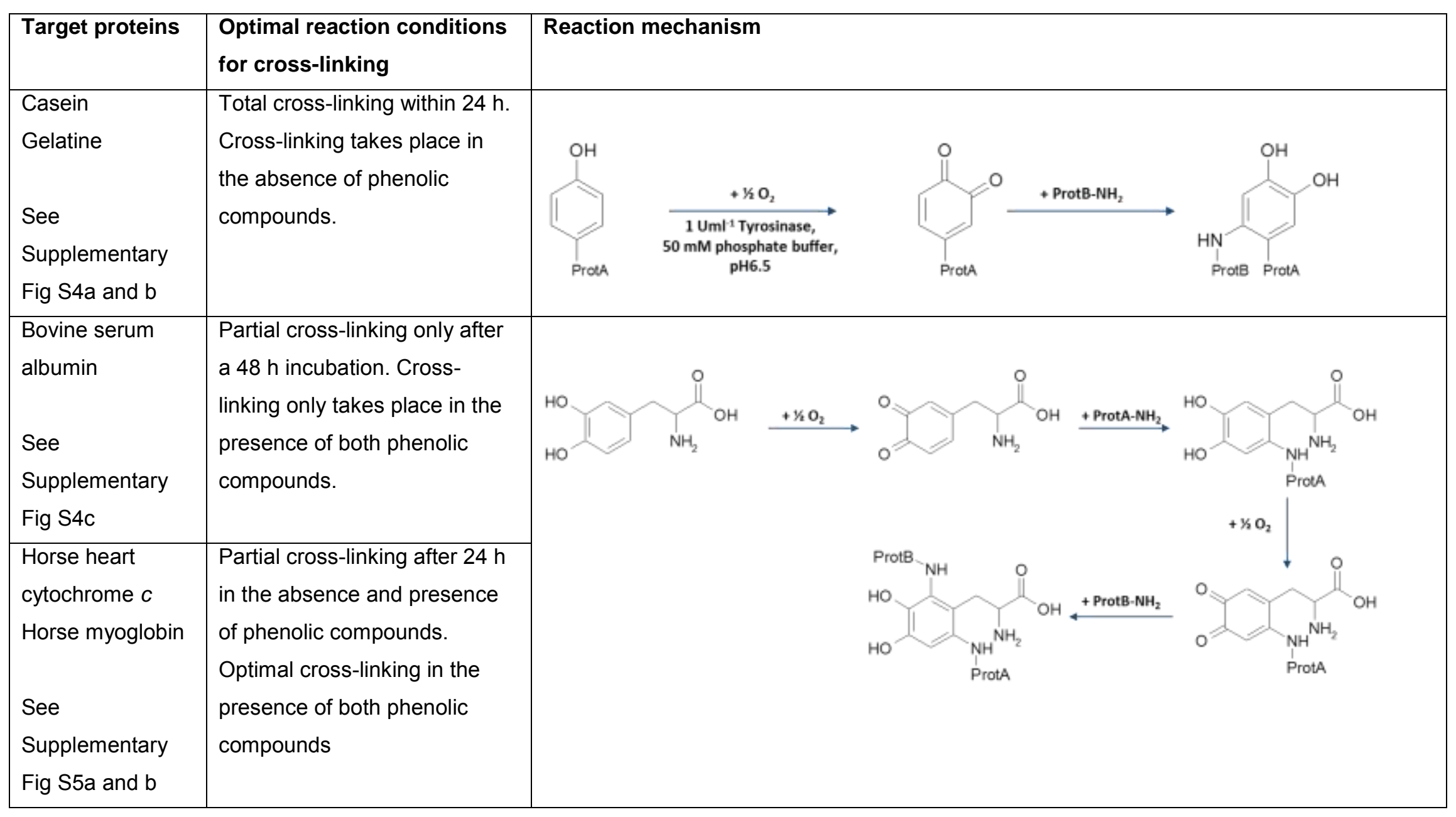


cross-linking of these two proteins was more prominent in the presence of L-DOPA and Ltyrosine. CZA14Tyr was more effective at cross-linking horse heart cytochrome $c$ than SPRTyr.

\section{Discussion}

The true biological role of tyrosinases in streptomycetes is still unclear, but it is proposed that they are involved in melanin production, and have putative roles in lignin degradation and selfdefence against toxic phenolics produced and released by plants [8]. Melanin production in solid media occurs readily in the presence of an inducing compound such as trace elements and amino acids (e.g. ISP6 and ISP7 agar media used in actinomycete systematics as an indicator of melanin production) [14]. A recent study by Guo et al. [22] defined a medium for optimal melanin production by Streptomyces kathirae. The optimal medium contained a high concentration of yeast extract $\left(37 \mathrm{~g} \mathrm{~L}^{-1}\right)$, salts $\left(\mathrm{NaCl}\right.$ and $\left.\mathrm{CaCl}_{2}\right)$, amylodextrin as a carbon source, and $\mathrm{CuSO}_{4}$. It is therefore not surprising, that melanin production and tyrosinase induction has been demonstrated in various studies. Held and Kutzner [23] showed that tyrosinase production in $S$. glaucescens can be induced by various amino acids: L-methionine, L-leucine, L-phenylalanine, but not L-tyrosine. Similarly, Ikeda et al. [24] showed that L-methionine induces production of tyrosinase in S. antibioticus, S. glaucescens and S. castaneoglobisporus, but not in Streptomyces michiganensis, where $\mathrm{Cu}^{2+}$ was found to induce tyrosinase production [23]. The addition of $\mathrm{Cu}^{2+}$ and glucose to the $S$. antibioticus culture medium has also been found to enhance the production of tyrosinase [25]. In this study, S. polyantibioticus $\mathrm{SPR}^{\top}$ and S. pharetrae CZA14 ${ }^{\top}$ were cultured on various solid media to determine their ability to produce melanin (Fig. 1), a possible indicator for tyrosinase production [1]. These media were also used as liquid media screens for tyrosinase production. Optimal production of tyrosinase was found to occur in the complex medium, MPPM, a medium typically used in the production of bioactive secondary metabolites [15]. In addition, similar to other streptomycete strains [23], the addition of $\mathrm{CuSO}_{4} \cdot 5 \mathrm{H}_{2} \mathrm{O}$ to the medium resulted in the induction of tyrosinase production in both strains, while the addition of L-methionine had a limited effect (data not shown). 
The production of CZA14Tyr was quite consistent, while difficulties were experienced with the production of the tyrosinase from S. polyantibioticus $\mathrm{SPR}^{\top}$. After an adjustment of the production temperature from $30^{\circ} \mathrm{C}$ to $22^{\circ} \mathrm{C}$, the production of SPRTyr was more consistent and reproducible. As indicated in the review by Faccio et al. [26], bacterial tyrosinases are typically produced at very low levels, especially since most have been produced from the native strains. The production levels observed for SPRTyr $\left(5.32 \mathrm{mg} \mathrm{L}^{-1}\right)$ and CZA14Tyr (16.97 $\left.\mathrm{mg} \mathrm{L}^{-1}\right)$ were higher than that previously observed for Streptomyces albus $\left(0.2 \mathrm{mg} \mathrm{L}^{-1}\right)$ [27]. Higher production levels for streptomycete tyrosinases have been reported, but were only achieved when the operon encoding for the tyrosinase was overexpressed either in the native strain (e.g. S. antibioticus at $20 \mathrm{mg} \mathrm{L}^{-1}$ and S. kathirae) $[28,29]$ or in an expression host (e.g. the tyrosinase from Streptomyces sp. REN-21 in E. coli at $54 \mathrm{mg} \mathrm{L}^{-1}$ ) [3]. SDS-PAGE analysis (Fig. 2) showed that the enzymes fall within the expected size range for streptomycete tyrosinases (29-35 kDa) [1] with SPRTyr at $30.5 \mathrm{kDa}$ and CZA14Tyr at $32.6 \mathrm{kDa}$ (MelC2 only). The MelC1-MelC2 complex is clearly visible for both enzymes (Fig. 2; 50-52 kDa).

Over the past decade, there has been a global move towards the implementation of a bio-based economy. This has led to an increased effort in the identification of biocatalysts that can be applied in bio-processes. In this study, the biochemical characterisation of the two partially purified tyrosinases revealed that both enzymes exhibit properties ideal for industrial application. Both enzymes are stable under alkaline conditions and are able to oxidize a range of substrates (Table 2), including 3-hydroxyanthranilic acid and o-aminophenol, which can potentially be used as substrates for the production of phenoxazinone-type antibiotics. Even though other proteins were visible in the SDS-polyacrylamide gel (Fig. 2), these proteins represented a small percentage of the total protein content, while in commercial tyrosinases, additional proteins may represent up to $97 \%$, depending on the source of the commercial enzyme [30]. Laccases and peroxidases are often considered to be the most likely enzymes to interfere with tyrosinase activity. No laccase activity or peroxidase activity was detected for the partially purified tyrosinases produced in this study. As expected, very low monophenolase:diphenolase ratios 
were obtained and both tyrosinases exhibited a much higher affinity for diphenols as compared to monophenols, a phenomenon reported for most bacterial tyrosinases [31]. Optimal oxidation of LDOPA occurred at different temperatures for the two enzymes (Fig. 3a), with optimal oxidation of L-DOPA occurring under ambient conditions for SPRTyr $\left(22-25^{\circ} \mathrm{C}\right)$. A bioprocess, such as the production of synthetic melanins, based on the application of SPRTyr would therefore not require any additional energy requirements. Furthermore, incubation of the enzymes at $40^{\circ} \mathrm{C}$ had an enhancing effect on both enzymes: more than $100 \%$ activity was detected after $1 \mathrm{~h}$ of incubation (Fig. 3b), making the enzymes suitable for application in processes requiring higher temperatures of up to $40^{\circ} \mathrm{C}$.

Many phenolic substrates used in biocatalysis reactions are insoluble in water and require enzymes that are resistant to the organic solvent used for solubilisation. The OSRT produced by Streptomyces sp. REN-21 [3,32] for example, retained $>80 \%$ activity in up to $30 \%(\mathrm{v} / \mathrm{v})$ ethanol, $20 \%(\mathrm{v} / \mathrm{v})$ acetone, and $20 \%(\mathrm{v} / \mathrm{v})$ DMSO after incubation for $20 \mathrm{~h}$. In this study, SPRTyr was found to be more stable than OSRT and CZA14Tyr in the presence of organic solvents (Fig. 4). Furthermore, both SPRTyr and CZA14Tyr retained more activity in the presence of 50\% methanol than the known organic solvent resistant OSRT [3]. As with OSRT, rapid loss of activity occurred in the presence of higher concentrations of acetone, acetonitrile, 2-propanol and DMSO.

SPRTyr had a $k_{\text {cat }} / K_{\mathrm{m}}$ value of $85.25 \mathrm{~s}^{-1} \mathrm{mM}^{-1}$ for the oxidation of $p$-cresol, which is higher than that reported for $S$. glaucescens $\left(48 \mathrm{~s}^{-1} \mathrm{mM}^{-1}\right.$ ) (calculated from values reported in [6]) and that determined for CZA14Tyr $\left(15.01 \mathrm{~s}^{-1} \mathrm{mM}^{-1}\right)$. In addition, both SPRTyr and CZA14Tyr exhibited much higher $k_{\text {cat }} / K_{\mathrm{m}}$ values for the oxidation of L-DOPA than previously reported at $2351.40 \mathrm{~s}^{-1}$ $\mathrm{mM}^{-1}$ and $2894.43 \mathrm{~s}^{-1} \mathrm{mM}^{-1}$, respectively. These values are between 3 to a 100 fold greater than those reported in literature: $23.5 \mathrm{~s}^{-1} \mathrm{mM}^{-1}$ for the Streptomyces sp. $\mathrm{KY}-453$ tyrosinase [33]; $250 \mathrm{~s}^{-1}$ $\mathrm{mM}^{-1}$ for the $S$. glaucescens tyrosinase (calculated from values reported in [6]); $271 \mathrm{~s}^{-1} \mathrm{mM}^{-1}$ for the Streptomyces sp. REN-21 OSRT [32]; $742.9 \mathrm{~s}^{-1} \mathrm{mM}^{-1}$ for the Streptomyces albus tyrosinase [27]; and $880 \mathrm{~s}^{-1} \mathrm{mM}^{-1}$ for the S. castaneoglobisporus tyrosinase [34]. The high affinity for L- 
DOPA, make SPRTyr and CZA14Tyr excellent candidates for application in the production of synthetic melanins and for application as biosensors for the detection of L-DOPA [10]. The fact that both enzymes retained $>80 \%$ residual activity in the presence of $25 \mathrm{mM}$-arbutin, EDTA, $\mathrm{NaCl}$ and SDS, as well as their ability to retain $100 \%$ activity in the presence of $5 \mathrm{mM} \mathrm{Ca}^{2+}, \mathrm{Mg}^{2+}$ and $\mathrm{Mn}^{2+}$, further supports their potential for application in biosensors. The strong inhibition by the reducing agents, L-ascorbic acid, L-cysteine and sodium metabisulphite, was to be expected, and probably results from the disruption of disulphide bridges in the protein structure. The ability of SPRTyr to retain activity in the presence of $1 \mathrm{mM}$ L-ascorbic acid, however, will allow for the use of this reducing agent in controlled biocatalysis reactions.

Scattered, non-standardised biochemical information and the general lack of sequence information on well-described tyrosinases precluded a direct comparison between SPRTyr, CZA14Tyr and their closest phylogenetic neighbours. The varied biochemical information available is most probably due to the fact that past studies were more focused a specific application (e.g. organic solvent tolerance or melanin production), rather than gauging the full biotechnological potential of the enzymes. The lack of sequence information, coupled to a general lack of access to the producing strains, have also made it difficult to perform comparative studies and to ensure the inclusion of suitable positive controls (e.g. many bacterial-based studies make use of mushroom tyrosinase as a positive control simply because of its commercial availability). Furthermore, the past two decades have seen a dramatic increase in the number of genomes being sequenced. Although these genomes serve as useful resources they do not provide any information on the potential biochemical properties or applications of the enzymes. It is therefore not surprising that the sequences with the highest similarity to SPRTyr and CZA14Tyr were tyrosinase sequences derived from genome sequencing events. The analysis of the MelC2 sequences, which relate to the tyrosinases described in this paper, allowed for the detection of the conserved histidine residues involved in the co-ordination of CuA and CuB (Supplementary Fig. S1), confirming the sequence-based classification of these enzymes as Type I tyrosinases (according to the classification proposed by [10]). Furthermore, the predicted pl for the MelC2 
sequences (9.92 and 10.03, for SPRTyr and CZA14Tyr, respectively) were similar to those reported for S. michiganensis $(\mathrm{pl}=9.0)$ [35] and Streptomyces sp. KY-453 (pl = 9.9) [33]. Future studies should consider sequence information, ensure that the producing organism is readily available (e.g. from international culture collections), and should include biochemical information that would determine the suitability of the enzyme for its application in bio-based processes as defined by the bioeconomy approach (e.g. ability to catalyse non-standard reactions, ability to function in the presence of organic solvents or other media, etc.).

In nature, a wide range of protein cross-linking processes occur [36]. Some of the industries that have explored this phenomenon include the food processing industry, leather and textile fabrication industry, and tissue engineering field [36]. Enzymes are considered to be viable alternatives to chemical cross-linkers such as gluteraldehyde and formaldehyde, which have related toxicity and expenses. Enzymes that have been explored as potential cross-linking agents include transglutaminases, peptidases, tyrosinases, laccases, peroxidases, and lysyl oxidases/amine oxidases [36]. For tyrosinases, tyrosine side chains on proteins act as a substrate and are converted to o-quinones which react spontaneously with lysine, tyrosine, histidine and cysteine residues, resulting in covalent protein-protein cross-linking [36]. Unfolded proteins therefore serve as the best substrates for tyrosinases, with limited cross-linking occurring when globular proteins are used. Cross-linking can also be induced through the addition of small phenolic compounds, which act as cross-linking mediators, thereby widening the range of proteins that can be cross-linked by tyrosinases [36]. In this study, limited cross-linking occurred when BSA, horse heart cytochrome $c$, and horse myoglobin were used as substrates (Table 4; Supplementary Fig. S4c and Supplementary Fig. S5) probably due to the lack of free tyrosyl side chains and the globular structure of the substrate proteins. However, enhanced cross-linking was observed when L-DOPA and L-tyrosine were added as phenolic mediators. In contrast, both tyrosinases were able to cross-link casein and gelatine without the addition of a phenolic compound (Table 4; Supplementary Fig. S4a and b). The cross-linking of casein in milk is believed to mitigate its allergenic properties; SPRTyr and CZA14Tyr therefore have potential for 
application in the dairy industry. In addition, biomimetic materials such as hydrogels, are often made from collagen or gelatine [36] and the ability of both enzymes to cross-link gelatine in the absence of a phenolic compound shows potential application in the production of biological scaffolds for tissue engineering and will be explored in future studies.

\section{Conclusions}

The unique properties of the tyrosinases produced by S. polyantibioticus $\mathrm{SPR}^{\top}$ and S. pharetrae $\mathrm{CZA} 14^{\top}$, such as their organic solvent stability, activity in the presence of organic solvents, broad $\mathrm{pH}$ stability, and activity in the presence of inhibitory compounds, make these enzymes ideal for application in biocatalysis, bioremediation and biosensor technology. In addition, their ability to cross-link certain target proteins allows for potential application in the production of novel biomaterials. These two novel tyrosinases are therefore useful additions to the arsenal of biotechnologically relevant enzymes with potential for application in bio-based processes as defined by the needs of a global bioeconomy.

\section{Acknowledgements}

This work was supported by the National Research Foundation (NRF) of South Africa for project funding [Grant No. 73691; New cross-linking enzymes to S.B.]; and the Cape Peninsula University of Technology (CPUT) University Research Funding awarded to M.LR-H. J.R. held an NRF Innovation Postdoctoral Fellowship during the course of this study and Z.P. an NRF Honours Scholarship. Any opinion, findings and conclusions or recommendations expressed in this material are those of the author(s) and therefore the NRF does not accept any liability in regard thereto.

\section{Conflict of Interest}

The authors declare that they have no conflict of interest. This research did not involve human or animal studies. Good laboratory practice was followed at all times during the course of this study. 


\section{References}

1. H. Claus, H. Decker, Syst. Appl. Microbiol. 29 (2006) 3-14.

2. M. Fairhead, L. Thöny-Meyer, J. Biotechnol. 150 (2010) 546-551.

3. M. Ito, K. Inouye, J. Biochem. 138 (2005) 355-362.

4. M. Huber, K. Lerch, Biochemistry 27 (1988) 5610-5615.

5. Y.B. Ryu, I.M. Westwood, N.S. Kang, H.Y. Kim, J.H. Kim, Y.H. Moon, K.H. Park, Phytomedicine. 15 (2008) 612-618.

6. K. Lerch, L. Ettlinger, Eur. J. Biochem. 31 (1972) 427-437.

7. A.M.D. Nambudiri, J.V. Bhat, P.V. Subba Rao, Biochem. J. 130 (1972) 425-433.

8. H.-Y. Yang, C.W. Chen, PLoS ONE 4 (2009) e7462.

9. Y. Matoba, T. Kumagai, A. Yamamoto, H. Yoshitsu, M. Sugiyama, J. Biol. Chem. 281 (2006) 8981-8990.

10. M. Fairhead, L. Thöny-Meyer, N. Biotechnol. 29 (2012) 183-191.

11. C. Popa, G. Bahrim, Innovat. Rom. Food. Biotechnol. 8 (2011) 1-7.

12. M. Le Roes-Hill, P.R. Meyers, Int. J. Syst. Evol. Microbiol. 59 (2009) 1302-1309.

13. M. Le Roes, P.R. Meyers, Syst. Appl. Microbiol. 28 (2005) 488-493.

14. E.B. Shirling, D. Gottlieb, Int. J. Syst. Bacteriol. 16 (1966) 313-340.

15. E. Graf, K. Schneider, G. Nicholson, M. Ströbele, A.L. Jones, M. Goodfellow, W. Beil, R.D. Süssmuth, H.-P. Fiedler, J. Antibiot. (Tokyo) 60 (2007) 277-284.

16. R.M. Atlas, (2004) Handbook of Microbiological Media (3rd edition). CRC Press, Boca Raton, FL.

17. M.M. Bradford, Anal. Biochem. 72 (1976) 248-254.

18. M. Mandel, J. Marmur, Use of ultraviolet absorbance-temperature profile for determining the guanine plus cytosine content of DNA in Methods in Enzymology (Grossman, L. and Moldave, K., eds) Vol. 12, (1968) p.195 - 206, Academic Press, New York.

19. R.K. Aziz, D. Bartels, A.A. Best, M. DeJongh, T. Disz, R.A. Edwards, K. Formsma, S. Gerdes, E.M. Glass, M. Kubal, F. Meyer, G.J. Olsen, R. Olson, A.L. Osterman, R.A. Overbeek, L.K. McNeil, D. Paarmann, T. Paczian, B. Parrello, G.D. Pusch, C, Reich, R. Stevens, O. Vassieva, V. Vonstein, A. Wilke, O. Zagnitko, BMC Genomics 9 (2008) 75; doi:10.1186/14712164-9-75. 
20. S.F. Altschul, W. Gish, W. Miller, E.W. Myers, D.J. Lipman, J. Mol. Biol. 215 (1990) 403-410.

21. J.D. Bendtsen, H. Nielsen, D. Widdick, T. Palmer, S. Brunak, BMC Bioinform. 6 (2005) 167; doi:10.1186/1471-2105-6-167.

22. J. Guo, Z. Rao, T. Yang, Z. Man, M. Xu, X. Zhang, FEMS Microbiol. Lett. 357 (2014) 85-91.

23. T. Held, H.J. Kutzner, J. Gen. Microbiol. 136 (1990) 2413-2419.

24. K. Ikeda, T. Masujima, M. Sugiyama, J. Biochem. 120 (1996) 1141-1145.

25. E. Katz, A. Betancourt, Can. J. Microbiol. 34 (1988) 1297-1303.

26. G. Faccio, K. Kruus, M. Saloheimo, L. Thöny-Meyer, Process Biochem. 47 (2012) 1749-1760.

27. A. Dolashki, A. Gushterova, W. Voelter, B. Tchorbanov, Z. Naturforsch. 64c (2009) 724-732.

28. L. Bubacco, E. Vijgenboom, C. Gobin, A.W.J.W. Tepper, J. Salgado, G.W. Canters, J. Mol. Catal. B Enzym. 8 (2000) 27-35.

29. J. Guo, Z. Rao, T. Yang, Z. Man, M. Xu, X. Zhang, S-T. Yang, FEMS Microbiol. Lett. 362 (2015) DOI: 10.1093/femsle/fnv041.

30. A. Rescigno, P. Zucca, A. Flurkey, J. Inlow, W.H. Flurkey, Enzyme Microb. Technol. 41 (2007) 620-627.

31. D. Hernández-Romero, A. Sanchez-Amat, F. Solano, FEBS J. 273 (2006) 257-270.

32. M. Ito, K. Oda, Biosci. Biotechnol. Biochem. 64 (2000) 261-267.

33. T. Yoshimoto, K. Yamamoto, D. Tsuru, D. J. Biochem. 97 (1985) 1747-1754.

34. P.Y. Kohashi, T. Kumagai, Y. Matoba, A. Yamamoto, M. Maruyama, M. Sugiyama, Protein Expr. Purif. 34 (2004) 202-207.

35. S. Philipp, T. Held, H.J. Kutzner, J. Basic Microbiol. 31 (1991) 293-300.

36. T. Heck, G. Faccio, M. Richter, L. Thöny-Meyer, Appl. Microbiol. Biotechnol. 97 (2013) 461475. 


\section{Supplementary Table}

Table S1: Substrates used in this study - structure, extinction co-efficient and the wavelength at which oxidation of the substrate was monitored.

\begin{tabular}{|c|c|c|c|c|}
\hline Substrate & Structure & $\begin{array}{l}\text { Extinction } \\
\text { co-efficient } \\
\left(\mathrm{M}^{-1} \mathrm{~cm}^{-1}\right)\end{array}$ & $\begin{array}{l}\text { Wavelength } \\
\text { to monitor } \\
\text { oxidation }\end{array}$ & Reference \\
\hline 2,4-DCP & & 21674 & $510 \mathrm{~nm}$ & [1] \\
\hline 2,6-DMP & & 14800 & $468 \mathrm{~nm}$ & [2] \\
\hline 3-HAA & & 18000 & $452 \mathrm{~nm}$ & [3] \\
\hline 4-methylcatechol & & 1433 & $400 \mathrm{~nm}$ & [4] \\
\hline 4-TBC & & 3300 & $475 \mathrm{~nm}$ & [5] \\
\hline 4-TBC & & 1150 & $400 \mathrm{~nm}$ & [5] \\
\hline ABTS & & 36000 & $420 \mathrm{~nm}$ & [3] \\
\hline Caffeic acid & & 1900 & $480 \mathrm{~nm}$ & [6] \\
\hline Catechol & & 740 & $410 \mathrm{~nm}$ & [7] \\
\hline Guaiacol & & 26600 & $470 \mathrm{~nm}$ & [8] \\
\hline
\end{tabular}




\begin{tabular}{|c|c|c|c|c|}
\hline L-DOPA & & 3600 & $475 \mathrm{~nm}$ & [9] \\
\hline L-tyrosine & & 3600 & $475 \mathrm{~nm}$ & [10] \\
\hline o-aminophenol & & 9600 & $433 \mathrm{~nm}$ & [11] \\
\hline p-cresol & & 1433 & $400 \mathrm{~nm}$ & [12] \\
\hline Phenol & & 7100 & $510 \mathrm{~nm}$ & [13] \\
\hline Pyrogallol & & 4400 & $450 \mathrm{~nm}$ & [14] \\
\hline Resorcinol & & 32800 & $500 \mathrm{~nm}$ & [14] \\
\hline Syringaldazine & & 65000 & $530 \mathrm{~nm}$ & [15] \\
\hline
\end{tabular}

\section{References}

1. B. Winter, A. Fiechter, W. Zimmerman, W. Appl. Environ. Microbiol. 57 (1991) 2858-2863.

2. F. Solano, P. Lucas-Elío, D. López-Serrano, E. Fernández, A. Sanchez-Amat, FEMS Microbiol. Lett. 204 (2001) 175-181.

3. C. Eggert, U. Temp, J.F. Dean, K.E. Eriksson, FEBS Lett. 376 (1995) 202-206.

4. E. Orenes-Piñero, F. García-Carmona, A. Sánchez-Ferrer, Enzyme Microb. Technol. 39 (2006) 158-163.

5. E. Orenes-Piñero, F. García-Carmona, A. Sánchez-Ferrer, J. Mol. Catal. B Enzym. 47 (2007) 143-148.

6. P. Hapiot, A. Neudeck, J. Pinson, H. Fulcrand, P. Neta, C. Rolando, J. Electroanal. Chem. 405 (1996) 169-176.

7. E. Nazaruk, A. Michota, J. Bukowska, S. Shleev, L. Gorton, R. Bilewicz, J. Biol. Inorg. Chem. 12 (2007) 335344.

8. C. Johannes, A. Majcherczyk, J. Biotechnol. 78 (2000) 193-199.

9. K. Kerch, L. Ettlinger, Eur. J. Biochem. 31 (1972) 427-437.

10. S. Castro-Sowinski, G. Martinez-Drets, Y. Okon, FEMS Microbiol. Lett. 209 (2002) 115-121.

11. H. Suzuki, Y. Furusho, T. Higashi, Y. Ohnishi, S. Horinouchi, J. Biol. Chem. 281 (2006) 824-833.

12. E. Orenes-Piñero, F. García-Carmona, A. Sánchez-Ferrer, J. Agric. Food Chem. 53 (2005) 1196-1200.

13. P. Trinder, Ann. Clin. Biochem. 6 (1969) 24-27.

14. K.N. Niladevi, N. Jacob, P. Prema, Process Biochem. 43 (2008) 654-660.

15. J.P. Ride, Physiol. Plant Pathol. 16 (1980) 187-192. 


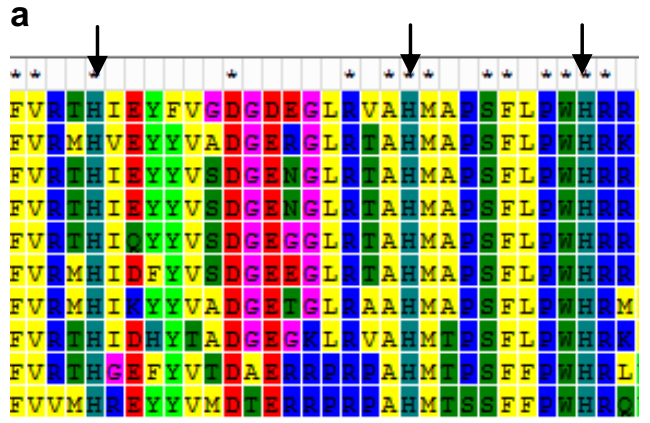

b

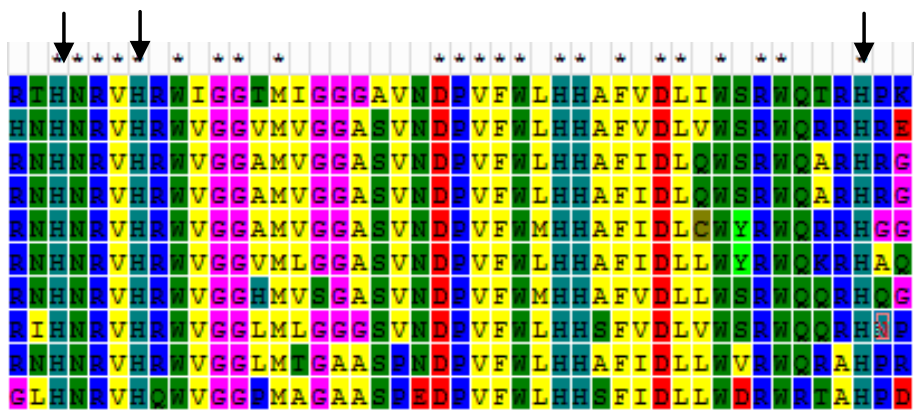

Fig. S1: Multiple sequence alignments for the identification of the CuA (a) and CuB (b) coordination sites. Histidine residues involved in the copper co-ordination are indicated by arrows. MelC2 sequences used in the alignment are as follow: $S$. polyantibioticus (this study; KR030067), S. pharetrae (this study; KR030068), Streptomyces lividans TK24 (EFD69188.1), Streptomyces coelicolor A3(2) (EFD69188.1), Streptomyces sviceus ATCC 29083 (EDY61099.2), Streptomyces acidiscabies 84-104 (ZP_10456104.1), Streptomyces avermitilis MA-4680 (NP_826539.1), Streptomyces venezuelae ATCC 10712 (YP_006880197.1), Streptomyces clavuligerus ATCC 27064 (EDY52544.1) and Streptomyces griseus subsp. griseus NBRC 13350 (YP_001822039.1). 


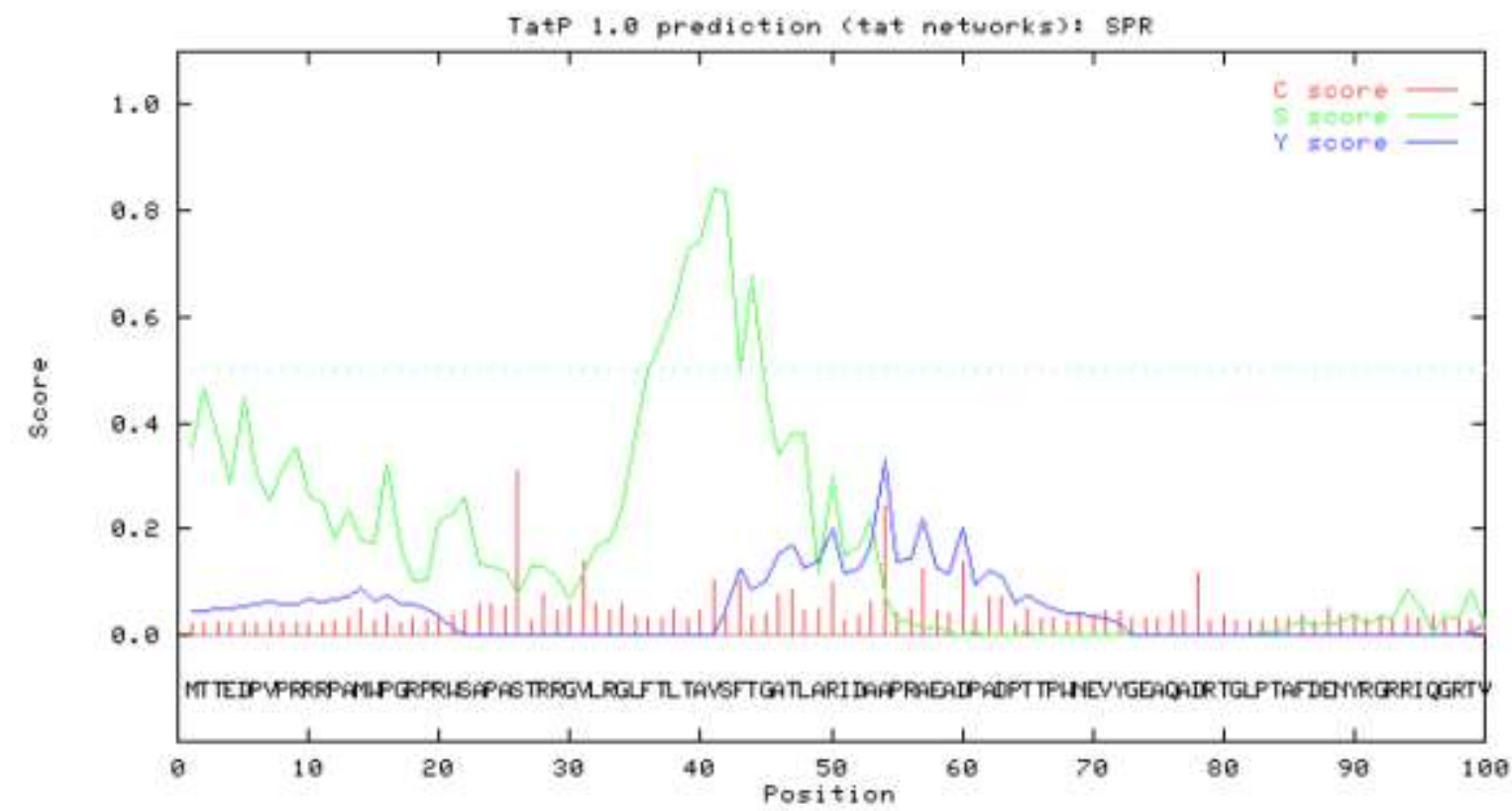

\# data

\begin{tabular}{|c|c|c|c|c|}
\hline \multicolumn{2}{|l|}{$>S P R$} & \multicolumn{2}{|c|}{ length $=160$} & \multirow{2}{*}{ Tat signal peptide? } \\
\hline \# Measure & Position & Value & Cutoff & \\
\hline $\max . C$ & 26 & 0.309 & 0.51 & NO \\
\hline $\max . Y$ & 54. & 0.332 & 0.35 & NO \\
\hline $\max . \mathrm{S}$ & 41 & 0.840 & 0.75 & YES \\
\hline mean $\mathrm{S}$ & $1-53$ & 0.308 & 0.30 & YES \\
\hline $\max . D$ & $1-53$ & 0.320 & 0.36 & NO \\
\hline
\end{tabular}




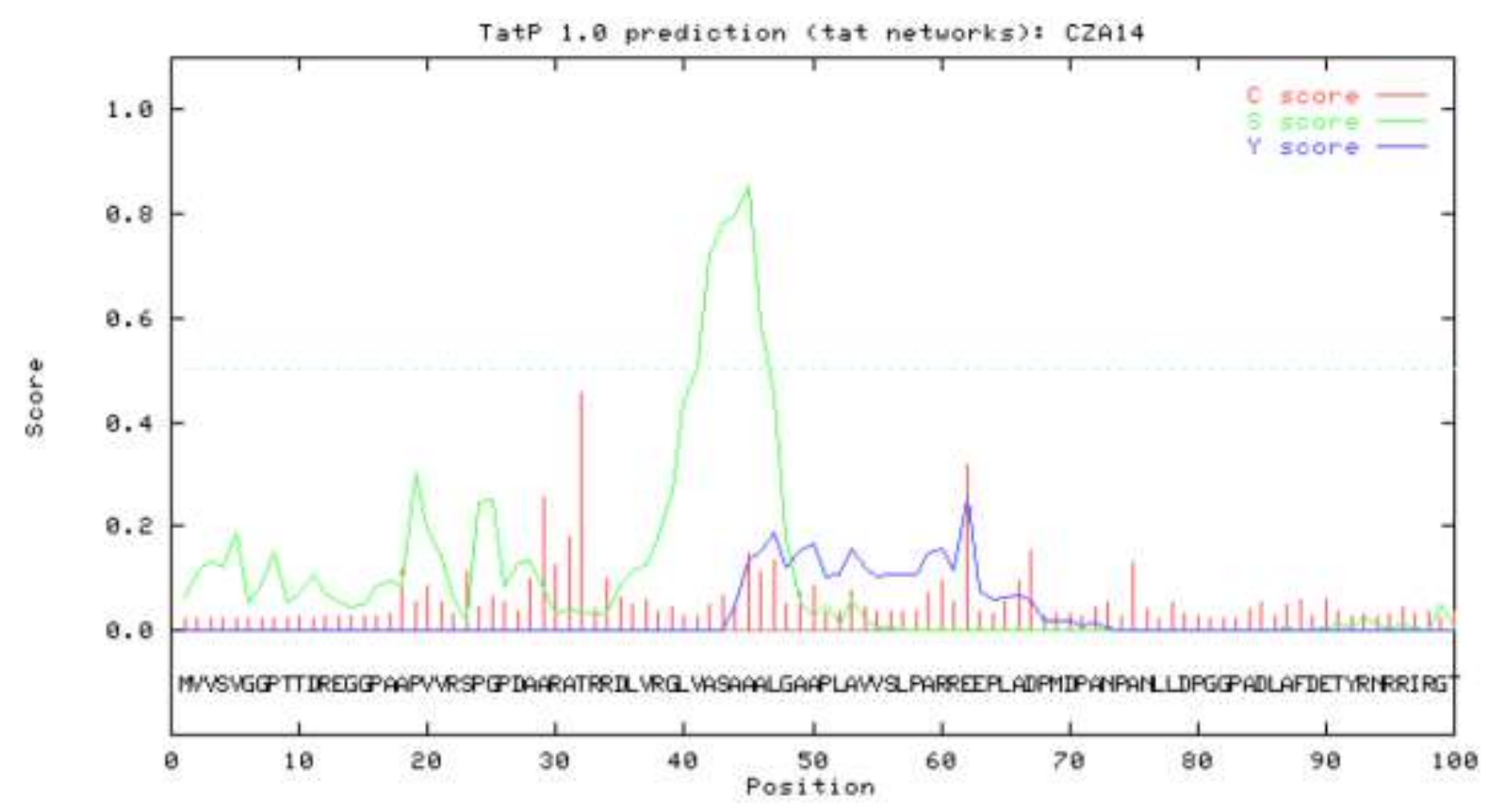

\# data

\begin{tabular}{|c|c|c|c|c|}
\hline >CZA14 & \multicolumn{3}{|c|}{ length $=100$} & \multirow{2}{*}{ Tat signal peptide? } \\
\hline \# Measure & Position & Value & Cutoff & \\
\hline $\max . \quad C$ & 32 & 0.455 & 0.51 & \\
\hline $\max . \mathrm{Y}$ & 62 & 0.256 & 0.35 & NO \\
\hline $\max . \mathrm{S}$ & 45 & 0.856 & 0.75 & YES \\
\hline mean $\mathrm{S}$ & $1-61$ & 0.161 & 0.30 & NO \\
\hline $\max . D$ & $1-61$ & 0.209 & 0.36 & No \\
\hline
\end{tabular}

Fig. S2: Analysis results for the presence of the TAT signal peptide in the MeIC1 sequences of (a) SPRTyr (KR030065) and (b) CZA14Tyr (KR030066). 


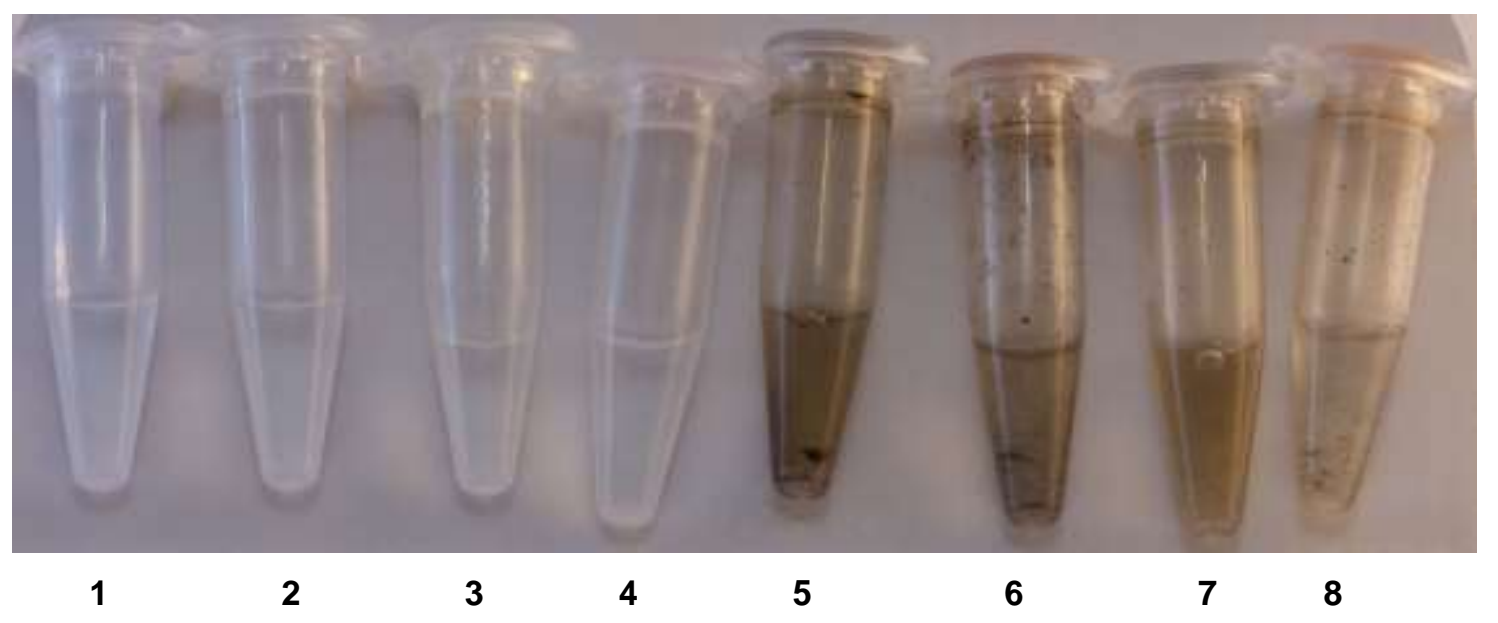

b

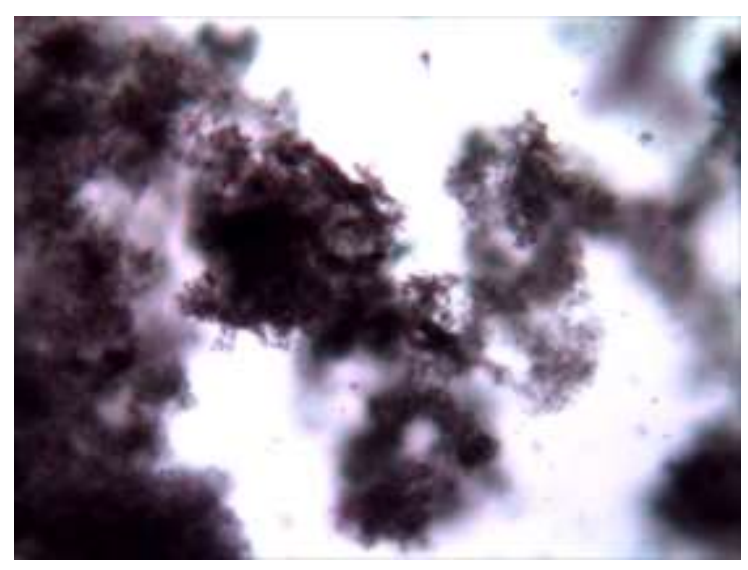

Fig. S3: Cross-linking of various proteins through the use of SPRTyr and CZA14Tyr. (a) Reaction vessels with cross-linking reactions in which gelatine was used as the target protein. Melanin formation and cross-linked material is clearly visible; (1: Gelatine; 2: Gelatine + SPRTyr; 3: Gelatine + CZA14Tyr; 4: Gelatine + L-DOPA/L-Tyrosine; 5: Gelatine + SPRTyr + L-DOPA; 6: Gelatine + SPRTyr + L-DOPA/L-tyrosine; 7: Gelatine + CZA14Tyr + LDOPA; and 8: Gelatine + CZA14Tyr + L-DOPA/L-tyrosine). (b) Sample taken from the gelatine cross-linking experiment and viewed with an Olympus light microscope (x400 magnification) showing the extensive matrix of cross-linked material. 


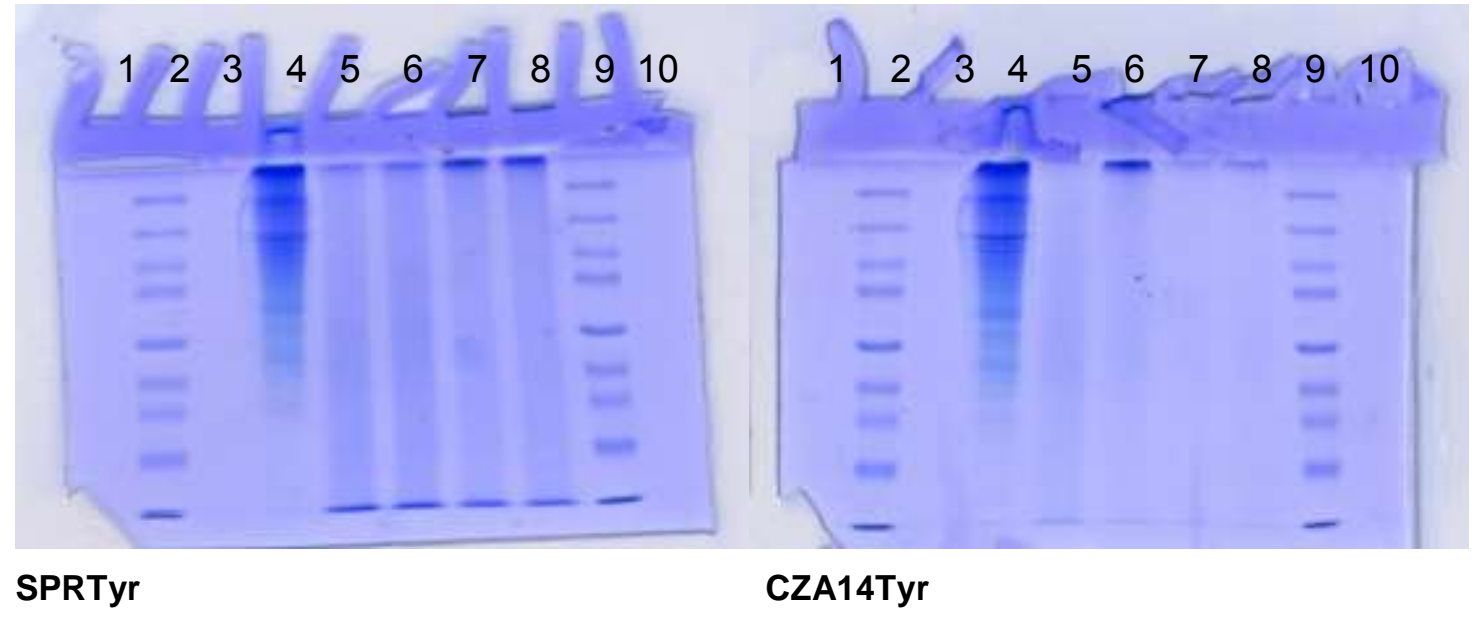

b

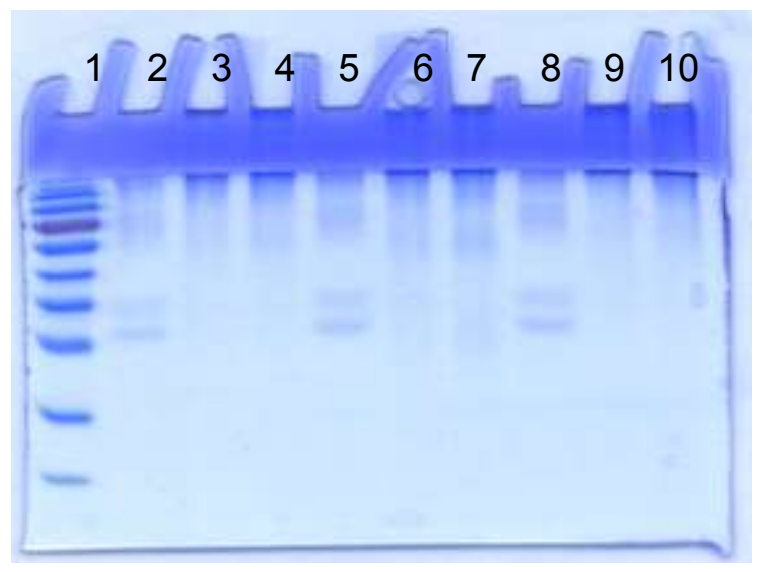

c

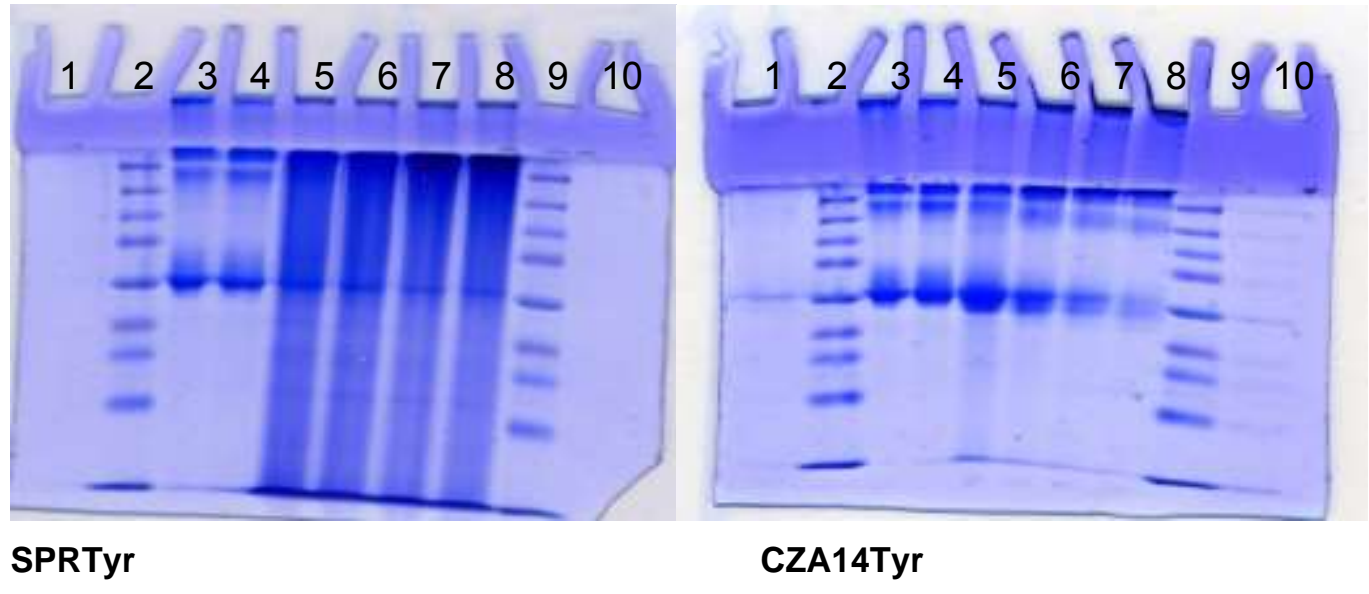

Fig. S4: SDS-PAGE gels of the following cross-linking experiments: a Gelatine (for both gels 1, 3 and 10: Empty; 2 and 9: Protein ladder; 4: Gelatine only; 5: Gelatine + tyrosinase; 
5: Gelatine + tyrosinase + L-DOPA; 6: Gelatine + tyrosinase + L-tyrosine; 7 and 8: Gelatine + tyrosinase + L-DOPA/L-tyrosine). b Casein (1: Protein ladder; 2: Casein only; 3: Casein + SPRTyr; 4: Casein + SPRTyr + L-DOPA/L-tyrosine; 5: Casein + L-DOPA/L-tyrosine; 6:

Casein + CZA14Tyr; 7: Casein + CZA14Tyr + L-DOPA/L-tyrosine; 8: Casein only; 9: Casein + S. antibioticus tyrosinase; and 10: Casein + S. antibioticus tyrosinase + L-DOPA/Ltyrosine). c BSA (for both gels 1 and 10: Empty; 2 and 9: Protein ladder; 3: BSA only; 4: BSA + tyrosinase; 5: BSA + tyrosinase + L-DOPA; 6: BSA + tyrosinase + L-tyrosine; 7 and 8: BSA + tyrosinase + L-DOPA/L-tyrosine). 


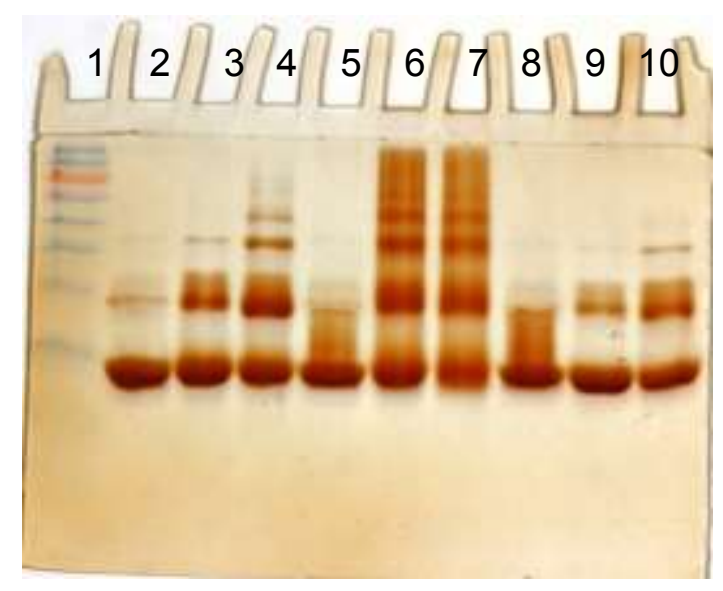

b

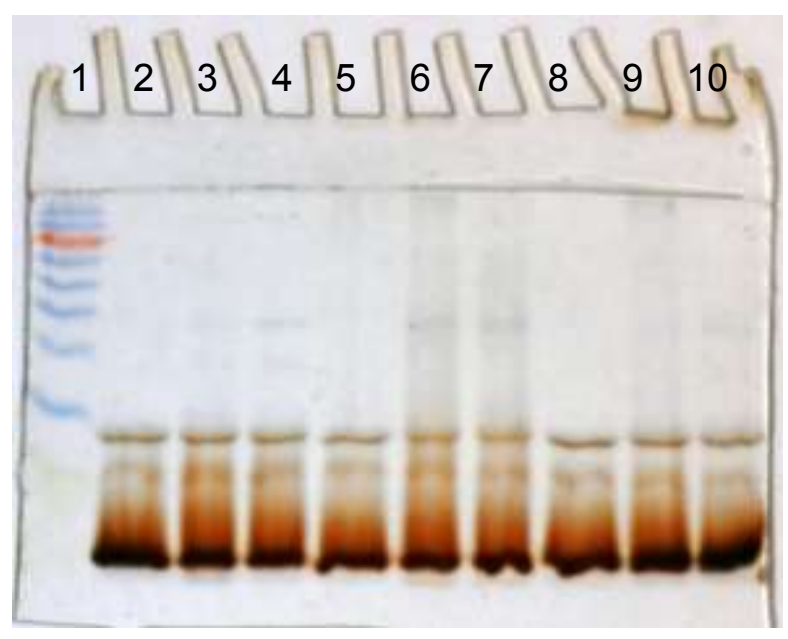

Fig. S5: SDS-PAGE gels of the following cross-linking experiments: a Horse heart cytochrome $c$ (1: Protein ladder; 2: Horse heart cytochrome $c$ only; 3: Horse heart cytochrome $c$ + SPRTyr; 4: Horse heart cytochrome $c$ + SPRTyr + L-DOPA; 5: Horse heart cytochrome $c$ + L-DOPA/L-tyrosine; 6 : Horse heart cytochrome $c$ + SPRTyr + L-DOPA/Ltyrosine; 7: Horse heart cytochrome $c+$ CZA14Tyr + L-DOPA/L-tyrosine; 8: Horse heart cytochrome $c$ only; 9: Horse heart cytochrome $c+$ CZA14Tyr; and 10: Horse heart cytochrome $c+$ CZA14Tyr + L-DOPA). b Horse myoglobin (1: Protein ladder; 2: Horse myoglobin only; 3: Horse myoglobin + SPRTyr; 4: Horse myoglobin + SPRTyr + L-DOPA; 5: Horse myoglobin + L-DOPA/L-tyrosine; 6: Horse myoglobin + SPRTyr + L-DOPA/L-tyrosine; 7: Horse myoglobin + CZA14Tyr + L-DOPA/L-tyrosine; 8: Horse myoglobin only; 9: Horse myoglobin + CZA14Tyr; and 10: Horse myoglobin + CZA14Tyr + L-DOPA). 
Streptomyces pharetrae CZA14 ${ }^{\top} \quad$ Streptomyces polyantibioticus SPR ${ }^{\top}$
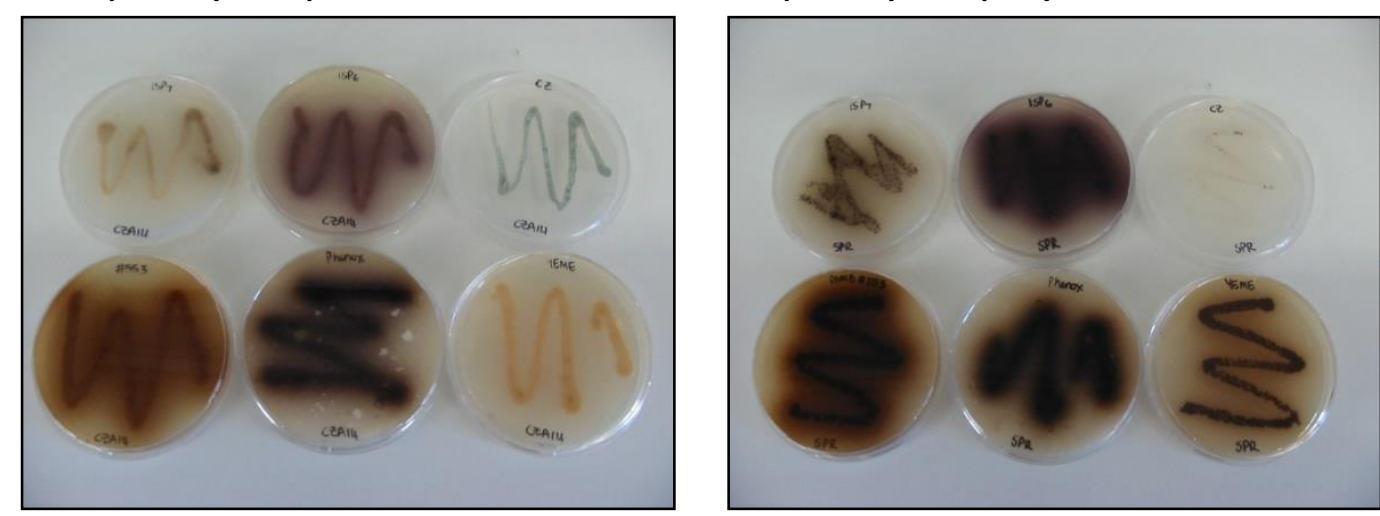

\section{Tyrosinase production}
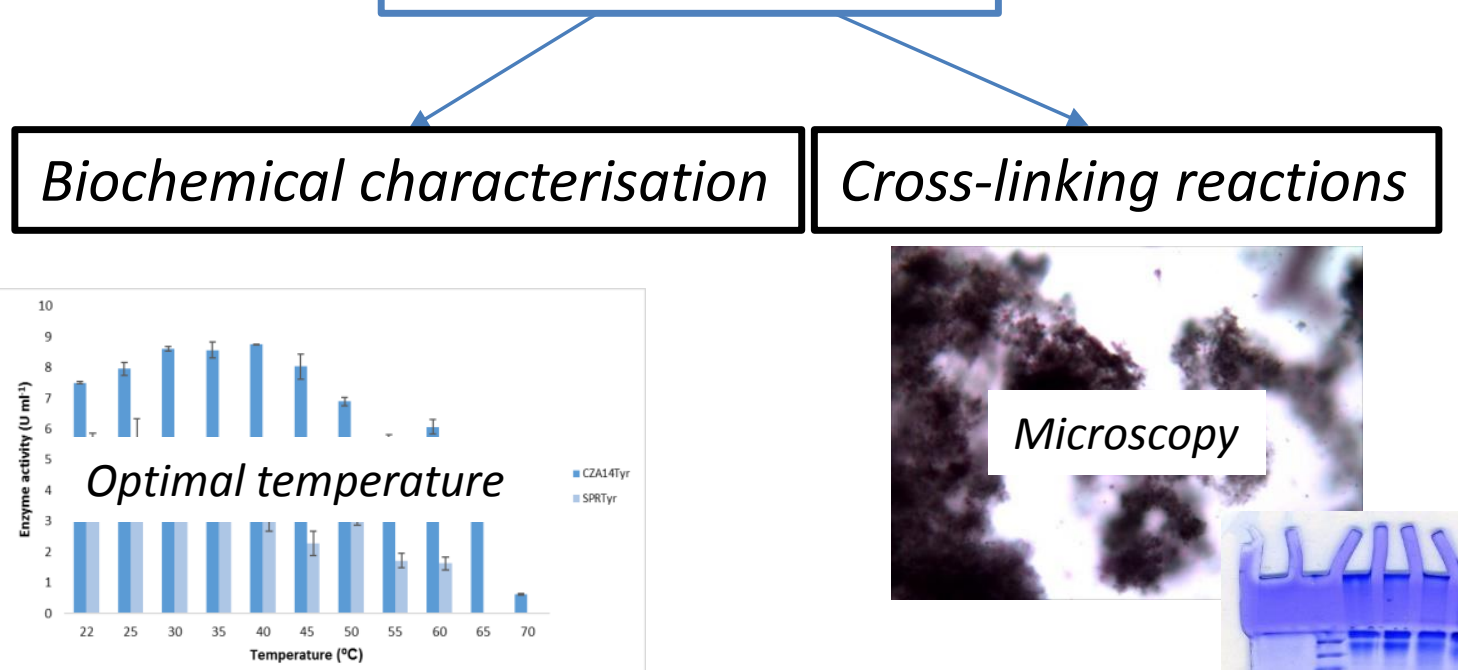

${ }^{190}$

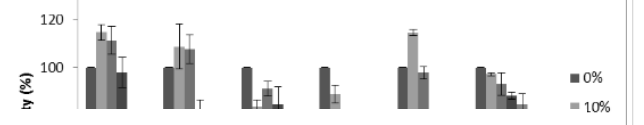
Organic solvent resistance illillill

- Temperature stability

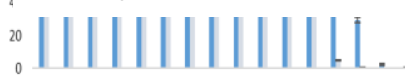

Graphical Abstract

Genome sequencing Identification of genes involved in tyrosinase production
Microscopy

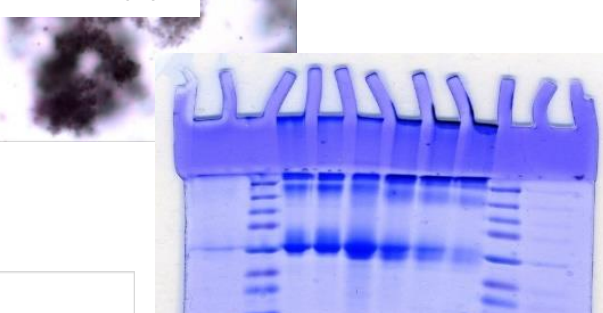

SDS-PAGE analysis

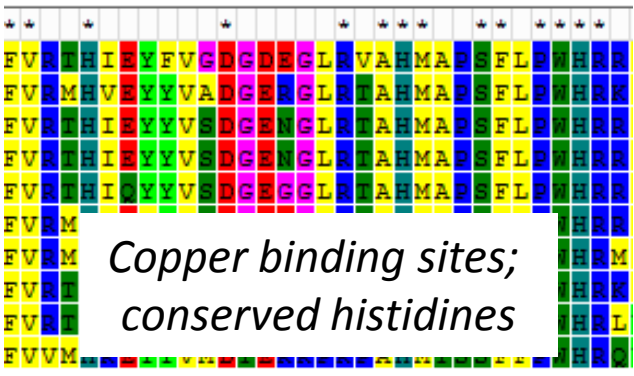

